\title{
Meeting report of the International Conference on the Great Lakes Region's Regional Training Facility: Working with the police sector to meet the needs of sexual violence survivors in the Great Lakes Region
}

\author{
Nathan Byamukama \\ Chi-Chi Undie \\ Population Council \\ Sharon Asiimwe \\ George Odwe \\ Population Council \\ Nachela Chelwa \\ Population Council
}

Follow this and additional works at: https://knowledgecommons.popcouncil.org/departments_sbsr-rh See next page for additional authors

Part of the Demography, Population, and Ecology Commons, Domestic and Intimate Partner Violence Commons, Family, Life Course, and Society Commons, Gender and Sexuality Commons, International

Public Health Commons, and the Medicine and Health Commons

How does access to this work benefit you? Let us know!

\section{Recommended Citation}

Byamukama, Nathan, Chi-Chi Undie, Sharon Asiimwe, George Odwe, Nachela Chelwa, Harriet Birungi, and Michael Mbizvo. 2019. "Meeting report of the International Conference on the Great Lakes Region's Regional Training Facility: Working with the police sector to meet the needs of sexual violence survivors in the Great Lakes Region." Kampala: ICGLR-RTF and Population Council. 


\section{Authors}

Nathan Byamukama, Chi-Chi Undie, Sharon Asiimwe, George Odwe, Nachela Chelwa, Harriet Birungi, and Michael Mbizvo 
Meeting Report of the International Conference on the Great Lakes Region's Regional Training Facility (ICGLR-RTF) and the Population Council

Working with the Police Sector to Meet the Needs of Sexual Violence Survivors in the Great Lakes Region
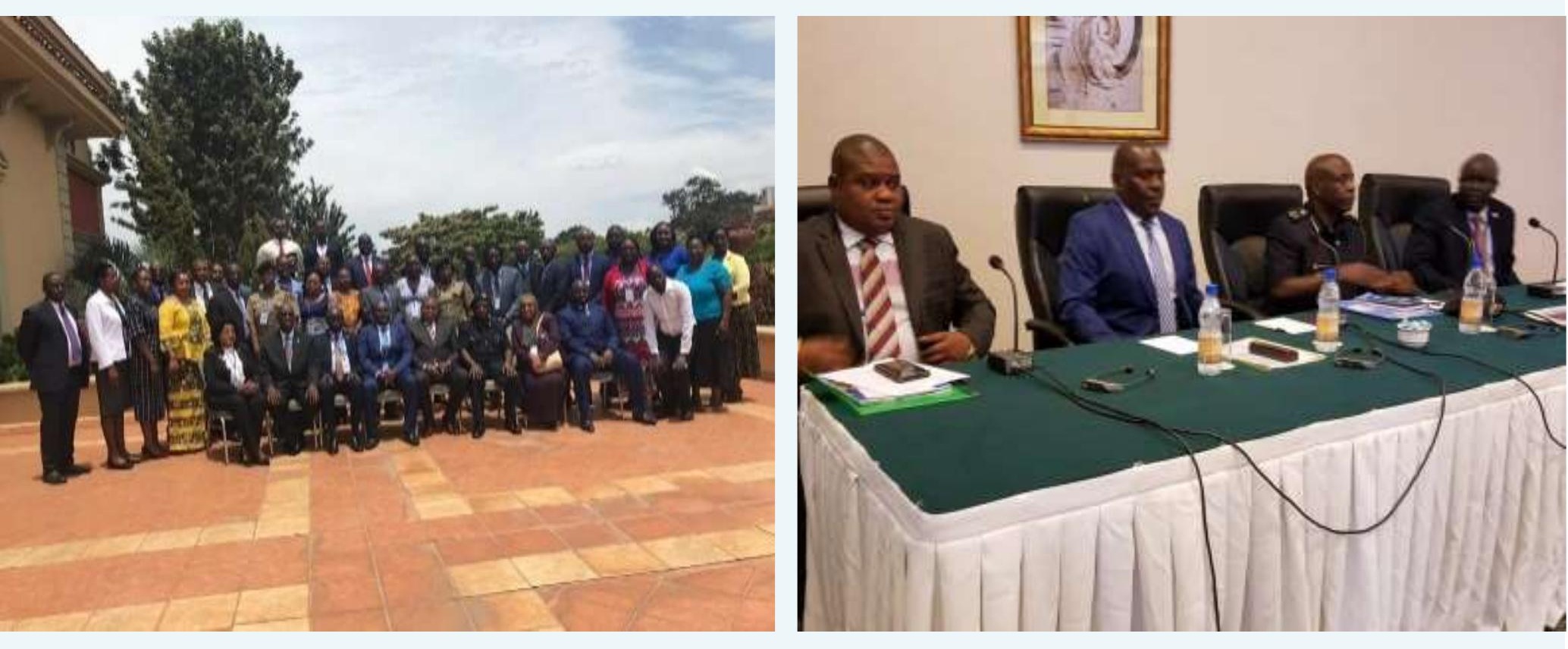

Lake Victoria Serena Hotel

Kigo, Uganda

April 8-9, 2019

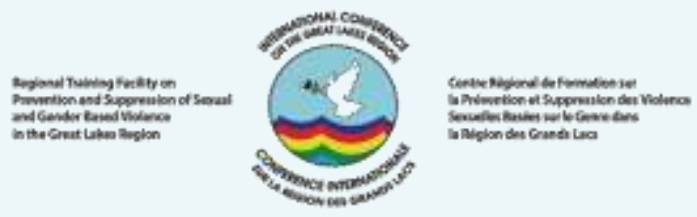


ICGLR Regional Training Facility

Yusufu-Luwaga Lane

Plot 1349 (off Salama Road), Munyonyo

P. 0. Box 1386

Kampala

Uganda

The ICGLR Regional Training Facility was established by 12 Member States of the International Conference of the Great Lakes Region (ICGLR) of Africa. It was set up as an implementation arm of the ICGLR to operationalize Article 6(9) of the ICGLR Protocol on the Prevention and Suppression of Sexual Violence against Women and Children (2006). It is a special regional facility for training and sensitizing judicial officers, police units, social workers, medical officers and other categories of persons who handle cases of sexual violence in the Great Lakes Region. Launched on 18 February 2014, the Regional Training Facility is based in Kampala, Uganda. It a decentralized organ of the ICGLR Secretariat based in Bujumbura, Burundi, and includes the following ICGLR Member States: Angola, Burundi, Central Africa Republic, Democratic Republic of Congo, Republic of Congo (Congo Brazzaville), South Sudan, Sudan, Kenya, Rwanda, Tanzania, Uganda and Zambia.

Suggested citation: Nathan Byamukama, Chi-Chi Undie, Sharon Asiimwe, George Odwe, Nachela Chelwa, Harriet Birungi, Mike Mbizvo. 2019. 'Meeting Report of the International Conference on the Great Lakes Region's Regional Training Facility: Working with the Police Sector to Meet the Needs of Sexual Violence Survivors in the Great Lakes Region.' ICGLR-RTF and Population Council.

(c) 2019 The International Conference on the Great Lakes Region's Regional Training Facility 


\section{Contents}

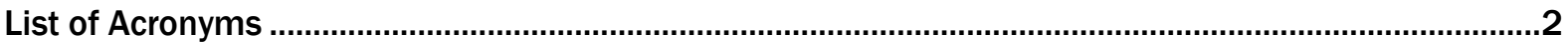

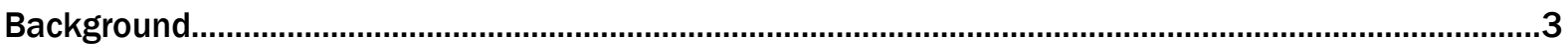

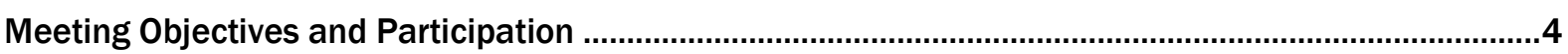

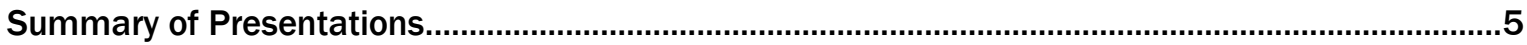

The ICGLR-RTF Training Program on Combatting SGBV ....................................................5

Member States' Presentations on Collaborations between Health and Police Sectors to Address SGBV .....................................................................................................................

Introduction to the Africa Regional SGBV Network....................................................................5

The Testimony of an SGBV survivor from the Great Lakes Region ..........................................6

Emergency contraception: A technical briefing.....................................................................6

Presentation on an innovative, police-led SGBV intervention: 'The Police Provision of Emergency Contraception' Model...............................................................................................6

The police provision of emergency contraception: History of regional policy engagement ......7

The Police Provision of EC Intervention: Discussion by Police Chiefs and Ministry of Health Representatives.........................................................................................................................

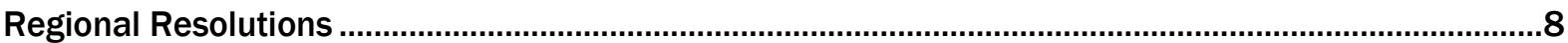

Background ........................................................................................... Error! Bookmark not defined.

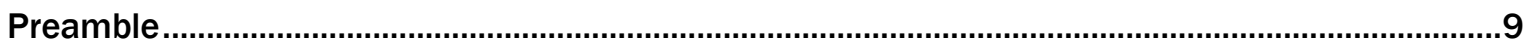

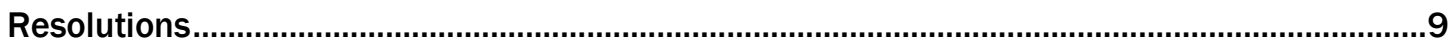

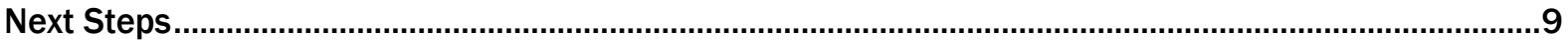

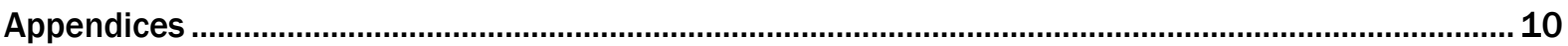

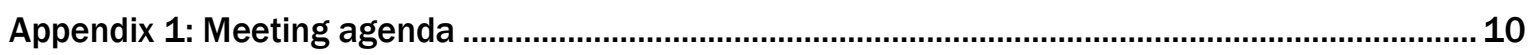

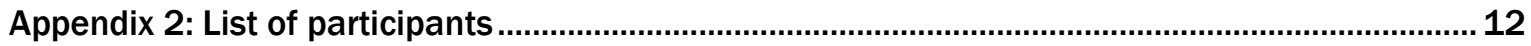

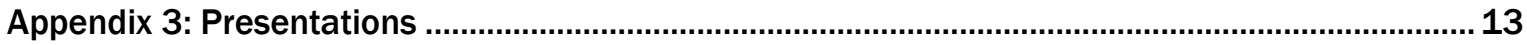




\section{List of Acronyms}

CAR Central African Republic

CBD Community-Based Distributor

DRC Democratic Republic of Congo

EAC East African Community

EC Emergency Contraception

GBVRC Gender-based Violence Recovery Centre

ICEC International Consortium for Emergency Contraception

ICGLR International Conference on the Great Lakes Region

IGP Inspector General of Police

$\mathrm{MoH} \quad$ Ministry of Health

RTF Regional Training Facility

SGBV Sexual and Gender-Based Violence

VSU Victim Support Unit 


\section{Background}

The Regional Training Facility (referred to as 'ICGLR-RTF') on the Suppression of Sexual Violence was established by 12 Member States of the International Conference on Africa's Great Lakes Region (ICGLR) an implementation arm to operationalize Article 6(9) of the ICGLR Protocol on the Prevention and Suppression of Sexual Violence against Women and Children (2006). ICGLR-RTF is a special facility for training and sensitizing judicial officers, police units, social workers, medical officers, and other persons who handle sexual violence cases in the Great Lakes Region. Launched in 2014 in Kampala, Uganda, it is a de-centralized organ of the ICGLR Secretariat based in Bujumbura, Burundi.

ICGLR-RTF partners provide financial and technical support to the institution in implementing ICGLRRTF activities for combating SGBV in the Great Lakes Region. The Population Council is one such partner that has collaborated with ICGLR-RTF to address SGBV in the region through technical and financial support since 2016. For over a decade, Population Council and its coalition of partners (referred to as the 'Africa Regional SGBV Network') have provided technical assistance (TA) and conducted research to strengthen the evidence base of sexual and gender-based violence (SGBV) programming in East, Horn, and Great Lakes region of Africa. This Network of partners has continuously developed, implemented, and evaluated core elements of a comprehensive, multi-sectoral response model since 2006. This response model incorporates the shared and complementary responsibilities of core sectors (police and justice, health, education, social services). It also recognizes that while SGBV survivors require access to all available services within these sectors, it may not be feasible, appropriate, nor cost effective to deliver all of these services in one location.

Africa Regional SGBV Network studies demonstrate that police services are often the first (and sometimes only) point of contact for sexual violence survivors ${ }^{1}$-and in refugee settings rates of unintended or unwanted pregnancy due to rape can be extraordinarily high. A recent Network study found that over half of refugee women in the region who reported ever experiencing non-partner rape have also experienced rape-related pregnancy as a result (56\%). ${ }^{2}$ These realities necessitate police sector coordination with other sectors (particularly the health sector) to meet survivors' immediate needs. Within the first 72 hours after an assault, both medical and legal responses are necessary to ensure both a survivor's health as well as the ability to prosecute a case. The necessity of coordinating medico-legal responses within a limited time makes links between these sectors a pre-requisite for effective institutional response to sexual violence, particularly in refugee settings.

Under the Africa Regional SGBV Network, the Population Council and its partners (Zambia Police Service and Zambia Ministry of Health) developed and tested an intervention specifically including police response to sexual violence survivors, with police provision of emergency contraception (EC) for survivors who present at police stations within 120 hours of an assault involving penetrative sex, followed referrals of these survivors to a health facility for further care. ${ }^{3}$

This innovative response model has been successfully tested by the Network with police in Zambia ${ }^{1}$ and Malawi ${ }^{4}$. Both studies reveal that EC provision by trained police to sexual violence survivors is both feasible and effective. During both interventions, trained Victim Support Unit (VSU) police provided EC to sexual violence survivors, with no adverse events or misuse reported. Trained VSU officers also consistently referred survivors to health facilities for further care after providing EC as appropriate.

\footnotetext{
1 Keesbury J, M Zama, S Shreeniwas. 2009. The Copperbelt Model of Integrated Care for survivors of rape and defilement: Testing the feasibility of police provision of emergency contraceptive pills. Population Council: Lusaka.

www.popcouncil.org/uploads/pdfs/2009RH_ZambiaCopperbeltModellntCare.pdf

Undie C, H Birungi et al. 2016. Effectiveness of a Community-Based SGBV Prevention Model in Emergency Settings in Uganda: Testing the 'Zero Tolerance Village Alliance' Intervention. Nairobi, Kenya: Population Council. www.popcouncil.org/uploads/pdfs/2016RH SGBVPreventionUgandaZTVA.pdf

$3 \mathrm{EC}$ is an essential element of post-rape care preventing unwanted pregnancy if taken within 120 hours of unprotected sex. EC contains the same hormones as oral contraceptive pills, and can be a discrete product (such as the brands Pregnon or Postinor-2) or high doses of oral contraceptives. Both regimens are proven safe and effective in preventing pregnancy. EC is not an abortifacient and will not harm an existing pregnancy.

4 MHRRC, Malawi Police Service, MoH. 2012. Testing the feasibility of police provision of emergency contraception in Malawi. MHRRC: Malaw www.svri.org/MHRRCEVALUATIONREPORT.pdf.
} 
Results from these studies prompted the Government of Zambia to request Population Council TA to scale this model nationally, and today Zambia's national police training curriculum specifies police EC provision. Study results also gained attention regionally, culminating in a meeting co-convened by Population Council and the East African Community (EAC)'s Department of Peace and Security, in Kigali, Rwanda, 3 to 5 December 2014. This meeting brought together police officers from the EAC, serving as a mechanism for informing them of the police-led model. The meeting resulted in a series of regional recommendations, including publicizing the model among EAC inspectors general of Police for their official endorsements.

\section{Meeting Objectives and Participation}

In response to the encouraging evaluation findings and regional recommendations for police EC provision, and prompted by the need to work more effectively with the police sector to respond to the needs of sexual violence survivors in the region, in April 2019 ICGLR-RTF and Population Council coconvened a meeting in Kigo, Uganda. This meeting aimed to:

1. Broaden awareness among police and health sector decision-makers of the innovative, police-led response model

2. Inform these decision-makers about an ongoing ICGLR-RTF initiative, for training National Trainers in each ICGLR Member State on various SGBV service delivery models, including police EC provision

3. Foster policy commitment to the promotion of this model in refugee and non-refugee settings

4. Foster expansion of the police EC provision model in East Africa refugee settings, and ultimately

5. Contribute to meeting the needs of sexual violence survivors on a wider scale.

ICGLR-RTF and Population Council worked with EAC's Department of Peace and Security to increase the visibility of the response model among critical decision-makers in the police and health sectors, and to promote the model's adoption in the region. The involvement of health sector decision-makers was critical, as EC use and distribution is part of the health sector's mandate.

The meeting drew participants $(n=55)$ from nine countries in the Great Lakes region: Burundi, Central African Republic, Democratic Republic of Congo, Kenya, Republic of Congo, South Sudan, Sudan, Uganda, Zambia. Participants included inspectors general of Police (IGPs) and their representatives, national reproductive health $(\mathrm{RH})$ division heads (from Ministries of Health) and their representatives, EAC's Peace and Security Department, and staff from ICGLR-RTF and Population Council's Kenya and Zambia offices. Two IGPs (from Democratic Republic of Congo and South Sudan) and two Assistant IGPs (from Uganda and Zambia) attended, while other countries' police sectors were represented by senior officials. Seven directors of national RH divisions also participated.

The meeting was structured around plenary sessions (which included presentations and discussion) and intra-national discussions:

- ICGLR-RTF Training Program on Combatting SGBV: Member States' Progress and Future Activities

- Member States' Presentations on Health and Police Sector Collaborations to Address SGBV

- Introduction to the Africa Regional SGBV Network

- Emergency Contraception: A Technical Briefing

- The Testimony of an SGBV Survivor from the Great Lakes Region

- Presentation of an Innovative, Police-led SGBV Intervention: 'The Police Provision of Emergency Contraception' Model

- Police EC Provision: History of Regional Policy Engagement

- Police EC Provision: Discussion by Police Chiefs and MoH Representatives. 


\section{Summary of Presentations}

All presentations are in the Appendix, but this section summarizes key points from the presentations.

\section{ICGLR-RTF Training Program on Combatting SGBV}

The first presentation discussed how ICGLR-RTF is a regional Center of Excellence that trains SGBV providers from a range of sectors (police, judiciary, medical, psycho-social) to promote a regional multisectoral SGBV response. ICGLR-RTF draws on a cascading model, via layers of trainers until a final target group is reached. ICGLR-RTF maintains 10 regional Master Trainers, and 120 National Trainers (10 per Member State), all selected through a competitive process. Training on various aspects of SGBV response is cascaded from the regional to national level through these sets of trainers. Master Trainers monitor the National Trainers, who then directly training a range of professional providers in each country, who then ensure survivors are reached with needed service delivery approaches. Over 1,000 providers have been trained through this mechanism, in a range of professional sectors.

\section{Member States' Presentations on Collaborations Between Health Sectors and Police to Address SGBV}

Presentations by Ministry of Health $(\mathrm{MoH})$ delegates focused on existing SGBV health and police sector collaborations in each country. Presentations demonstrated that the vast majority of ICGLR-RTF Member States already recognize the importance of police and health sector collaborations, providing numerous examples. Some countries have prioritized early detection of SGBV survivors through community-based early warning systems, which foster a multi-sectoral approach and utilize mobile phones (as in Burundi), while others focus on rapid multi-sectoral services to survivors through special, non-health facility government units (e.g. 'Mixed Unit for Rapid Intervention and Repression' in Central African Republic).

Delegates also reported instances where the police and health sectors directly collaborate. In Kenya, police representatives act as trainers in MoH's national SGBV training initiatives. In some countries, police are signatories on the national post-rape care form (Kenya, South Sudan), while in others police were involved in revising these forms to ease survivors' access to justice (as in Uganda). Extant memoranda of understanding between the police and health sectors also ensure comprehensive care for survivors (South Sudan), and of medical and psycho-social management of survivors by the Ministry of Security (rather than solely under $\mathrm{MoH}$ ), demonstrating further multi-sectoral commitment (in the Central African Republic).

South Sudan, Uganda, and Zambia have incorporated SGBV instruction in the pre-service training of their police colleges, while the Republic of Congo began planning to introduce a police-led EC intervention, but has experienced funding issues with training costs and training manual development.

\section{Introduction to the Africa Regional SGBV Network}

The Network was described as specifically comprising SGBV-focused service delivery organizations ('Network partners') who, under Population Council leadership, work together to respond to SGBV regionally, through police stations, health facilities, schools, and communities, in additional to national policy. A mechanism for learning, exchange, and strategic action, the Network provides TA for SGBV interventions, including intervention design, capacity-building for intervention implementation, intervention monitoring, evaluation and documentation, and strategic dissemination of information for wide utilization of SGBV interventions. The Network's focus is on countries in the East, Horn, and Great Lakes regions of Africa, representing the majority of countries in the ICGLR region. The Africa Regional SGBV Network's current work centers on refugee settings, and transferring the Network's tested SGBV interventions to refugee contexts, while continuing to influence policy and programming in the region. 


\section{Testimony of an SGBV Survivor from the Great Lakes Region}

A critical part of the meeting was the live testimony by a rape survivor from Kenya. The woman's assault occurred nearly a decade ago, and she is thriving after long term (of years) psycho-social support at the Gender-Based Violence Recovery Centre (GBVRC) at Kenyatta National Hospital, Nairobi. At the time of the incident, this survivor was an unemployed single mother, who had traveled from Nairobi to another town in response to a job advertisement. The rape occurred at an office in a multi-story building in a busy part of the city center. She entered the building to submit her application and was subsequently raped at knifepoint.

The survivor unsuccessfully sought help at a nearby police station, due to the inadequate response of the available female police officer, who evidently had no training in proper SGBV protocol. The incident occurred on a Friday and the victim was asked to return to the station on Monday. Having no support and no further information, she did not preserve her clothing nor any other evidence. Discouraged by the lack of support and traumatized by the incident, she returned home.

Several weeks later, the victim began to feel nauseated and discovered she was pregnant-which traumatized her further and led to suicidal thoughts. After several unsuccessful attempts at pregnancy self-termination, she resigned herself and had a second child. For years, she viewed the child as a symbol of her trauma and struggled emotionally. Through the painstaking support of GBVRC, she eventually found solace and is currently a successful businesswoman who shares her story with providers to put a human face to decisions affecting SGBV programming and policy.

Had the police officer the survivor encountered been trained on SGBV as well as police EC provision, the unintended pregnancy could easily have been averted, and the rape-induced trauma could have been limited. This testimony was a significant precursor to the presentation on police EC provision.

\section{Emergency Contraception: A Technical Briefing}

A technical briefing on EC preceded the presentation on the police EC provision model, which is based on recommendations from the International Consortium for Emergency Contraception (ICEC) and Population Council. The presentation aimed to dispel common EC myths, specifying what exactly EC is, why it is used, and how, emphasizing its safety and importance in post-rape care. An important aspect of the presentation focused on the timing of EC's effects, such as the fact EC pills work before fertilization and do not work after the fertilization process.

\section{Presentation of an Innovative, Police-led SGBV Intervention: 'Police Provision of Emergency Contraception' Model}

The police EC provision model was developed by Population Council in collaboration with Zambia's Police Service and $\mathrm{MoH}$ as part of the Africa Regional SGBV Network. The model emerged in response to findings from a Population Council formative study revealing that police in Zambia are often the first and only points of contact for survivors seeking services. Survivors were thus at increased risk for unintended pregnancy.

As a means of enhancing survivors' access to care, the intervention specifically trained VSU police officers for provision of EC to eligible sexual violence survivors of reproductive age who present at police stations, combining this service with referrals (either through information or by actual accompaniment) to a health facility for comprehensive care. Survivors ages 10 and older are screened by VSU police officers for EC eligibility, using a checklist.

The intervention involves close collaboration between the police and health sectors, including joint training of police and health providers in addition to cross-sectoral training (with health providers training police to administer EC), EC supply for police by the health sector, joint supervision by the police and health sectors, and cross-sectoral steering committees with meetings at police stations or health facilities chaired by senior host institution staff. 
A 2006 evaluation of the intervention revealed that over three years VSU police officers in the Zambia study sites successfully provided nearly 400 doses of EC to sexual violence survivors who presented at police stations, with no adverse events or complaints. The vast majority of survivors who received EC (85\% were children ages 18 and younger) were also referred to a health facility for comprehensive care.

Police provision of EC has been scaled up in Zambia: It is fully integrated within the country's current (2012) national guidelines for managing SGBV survivors, and has been incorporated in Zambia's police pre-service and in-service training curricula.

\section{Police Provision of Emergency Contraception: History of Regional Policy}

This presentation reminded delegates that regional conversations about the police EC provision model began in 2014 at a police officers' meeting convened by EAC's Peace and Security Department and Population Council. At this meeting, police officers were informed about two Africa Regional SGBV Network police-centric models: police EC provision and multi-sectoral SGBV training of both police and health providers (led by Network partner LVCT Health). 5 This 2014 meeting led to the 2019 convening by ICGLR-RTF and Population Council, as it culminated in recommendations to EAC chiefs of Police at their ensuing meeting, where they:

1. Directed the Secretariat to organize learning exchange visits of EAC police to Zambia's and Kenya's police services to facilitate adaptation of the (two police-focused Africa Regional SGBV Network) models to suit EAC or individual countries, and

2. Directed Partner States to consider incorporating the police EC provision model within the EAC Partner States' Police Training Curriculum.

\section{The Police Provision of EC Intervention: Discussion by Police Chiefs and Ministry of Health Representatives}

All Member States concluded that the police EC provision model would be feasible to implement in their own countries. The table summarizes the plenary discussions and reports by individual countries:

\begin{tabular}{|c|c|}
\hline Member State & Comments on the Police EC Provision Model \\
\hline Burundi & $\begin{array}{l}\text { The model can be adopted/adapted. If community health workers can distribute EC, } \\
\text { can police can, who must be trained. MoH and police must decide how to collaborate. } \\
\text { Things to think about: } \\
\text { - Transfer of EC from MoH to Police } \\
\text { - Documentation } \\
\text { - What type of training needed; who will train? } \\
\text { - Must incorporate intervention in pre-service training, with refresher course } \\
\text { - Referral mechanisms }\end{array}$ \\
\hline $\begin{array}{l}\text { Central African } \\
\text { Republic }\end{array}$ & $\begin{array}{l}\text { The model is feasible for implementation, and would help promote decentralization: } \\
\text { - Workshop with police and their heads } \\
\text { - Outline plan of action } \\
\text { - Mapping of police posts close to health facilities in various regions } \\
\text { - Identify SGBV training needs of police }\end{array}$ \\
\hline $\begin{array}{l}\text { Democratic } \\
\text { Republic } \\
\text { of Congo }\end{array}$ & $\begin{array}{l}\text { It is possible to adapt this model: } \\
\text { - Police in DRC have an SGBV Unit at provincial level } \\
\text { - Training police at police stations and posts would be needed } \\
\text { - Health facilities in proximity to police stations permit collaboration } \\
\text { - Need to ensure careful oversight of the dispensing of EC by police }\end{array}$ \\
\hline
\end{tabular}

\footnotetext{
5 More information: Ajema C, W Mukoma, R Kotut, R Mulwa. 2015. Documenting medico-legal evidence in Kenya: Potential strategies for improvement BMC Proceedings 9(Suppl 4): A2. www.ncbi.nlm.nih.gov/pmc/articles/PMC4496633; Ajema C, W Mukoma, C Mugyenyi, M Meme, R Kotut, R Mulwa. 2012. Improving the collection, documentation and utilisation of medico-legal evidence in Kenya; LVCT Kenya.
} 


\begin{tabular}{|c|c|}
\hline Kenya & $\begin{array}{l}\text { It is possible to implement the model in Kenya due to existing structures (policies, } \\
\text { etc.) and goodwill (from Independent Police Oversight Authority): } \\
\text { - All police stations in Kenya have Gender Desks; then MoH supply chain; each } \\
\text { county has health facilities. Contraceptives are free } \\
\text { - The intervention should begin with the Gender Desk officers } \\
\text { - Commodity supply should come from health facilities nearby police stations } \\
\text { - Awareness-creation around the model at national level would be needed; can be } \\
\text { done through police forums ('community policing') and the media } \\
\text { - Need for a simple reporting tool for police stations, and for referral }\end{array}$ \\
\hline $\begin{array}{l}\text { Republic } \\
\text { of Congo }\end{array}$ & $\begin{array}{l}\text { - About to start implementing a police-led model involving EC, but not heard about } \\
\text { Zambian model: Would like Network TA } \\
\text { - Need funding for training and developing a manual for police and EC }\end{array}$ \\
\hline South Sudan & $\begin{array}{l}\text { - The model is appropriate for application in South Sudan } \\
\text { - Formative research needed, including baseline: Who are survivors? Where do they } \\
\text { actually tend to report first (police, like in Zambia)? This will help identify gaps, } \\
\text { and help sensitization and awareness-raising } \\
\text { - Develop a concept note and proposal for this model }\end{array}$ \\
\hline Sudan & $\begin{array}{l}\text { Same comments as Burundi (initial discussion together)-model is feasible in Sudan: } \\
\text { - Consider transfer of EC from MoH to Police } \\
\text { - Documentation } \\
\text { - What type of training needed; who will train } \\
\text { - Must incorporate intervention in pre-service training, with a refresher course } \\
\text { - Referral mechanisms }\end{array}$ \\
\hline Uganda & $\begin{array}{l}\text { This is a feasible model, and Uganda shall adopt it. } \\
\text { - Directorate of Health resources, police clinics, health workers, training schools } \\
\text { (curricula include SGBV), and collaborations with MoH, would make it easy to do } \\
\text { - National health policy allows community EC provision, so police won't be an issue } \\
\text { - Present model to top Police Council (of which the Director of Health is part) for } \\
\text { policy change; when Council approves, joint health and police training can occur } \\
\text { - Requirements: MoH supply commitments, accurate inventories, tool development } \\
\text { - Need for funding to make this model happen } \\
\text { - Topics on EC provision by police can be included into their police training curricula }\end{array}$ \\
\hline Zambia & $\begin{array}{l}\text { The Zambian delegation appreciates Member State approval of the model: } \\
\text { - Next steps in Zambia include scaling up the model further (beyond the } 2 \text { regions } \\
\text { with largest populations, Copperbelt and Lusaka). The plan is to implement the } \\
\text { model through the police sector by targeting the country's } 10 \text { provinces } \\
\text { - Community-based distributors (CBDs) in Zambia already know how to administer } \\
\text { EC. CBDs should therefore work with police posts as a means of scale up } \\
\text { - The model is now part of both police pre-service and in-service training curricula } \\
\text { - Transportation services between police stations and health facilities need to be } \\
\text { strengthened to enhance efficacy-how outlined recently in a Network study }\end{array}$ \\
\hline
\end{tabular}

\section{Regional Resolutions}

In an unprecedented manner, the testimony of the SGBV survivor from the Great Lakes Region permeated the plenary discussion of regional resolutions developed by the delegates. Many of the resolution suggestions from delegates were prefaced by references to this testimony, and the need for the proposed resolutions.

\footnotetext{
Chelwa N, K Hemal, GM Phiri, MT Mbizvo, C Undie. 2017. Enhancing access to post-rape care for child survivors in the context of police and health services in Zambia: Report on a police response model tested in Zambia. Lusaka: Population Council, www.popcouncil.org/uploads/pdfs/2017RH PoliceResponseSGBV-Zambia.pdf.
} 


\section{Preamble}

- Recognizing that SGBV is a pervasive problem in all ICGLR Member States, adversely affecting the lives of citizens

- Acknowledging the urgent health and psycho-social support needs of survivors

- Realizing that the police EC provision to sexual violence survivors has been tested elsewhere in the region (Zambia and Malawi) and has been proven feasible and effective

- We (Member States) agree on the following resolutions, urging the following:

\section{Resolutions}

1. ICGLR-RTF to support the training of a range of professionals to ensure the establishment of a multi-sectoral approach in the Great Lakes Region to combat SGBV

2. Member States' chiefs of Police to integrate EC provision by trained police officers to sexual violence survivors within police station services in the region

3. ICGLR-RTF and its partners to support Member States to effect such integration

4. Member States' Police chiefs and MoH to develop working relationships to facilitate integration

5. ICGLR-RTF and its partners to support formative research in selected countries to generate information to facilitate adaptation of the police EC provision model

6. ICGLR-RTF to standardize SGBV training curricula for police and health sectors in the Great Lakes

7. ICGLR-RTF to integrate the police EC provision model into training curricula

8. Population Council to widely disseminate research findings of police EC provision model in the Great Lakes region, and continue to generate and share other SGBV-related evidence

9. Member States' chiefs of Police to ensure creation of safe spaces for attending to survivors (including both physical spaces and police attitudes), and

10. Member States to strengthen mechanisms for handling SGBV perpetrators to bring them to justice and fight impunity.

\section{Next Steps}

The regional resolutions will be employed by ICGLR-RTF and its partners as advocacy ammunition to advocate for programs, funds, and other resources to foster integration of the police EC provision model at police stations in Member States (including refugee contexts) and beyond. In collaboration with ICGLR-RTF and EAC Department of Peace and Security, the Population Council-led Africa Regional SGBV Network will explore the possibility of a regional training for ICGLR-RTF Master Trainers and EAC police trainers on the model's implementation. 


\section{Appendices}

\section{Appendix 1: Meeting agenda}

\begin{tabular}{|c|c|c|c|}
\hline \multicolumn{4}{|c|}{ Day 1: Monday, April 8, 2019} \\
\hline & TOPIC & FACILITATORS & CHAIR \\
\hline $8: 30-9: 00$ & Registration & ICGLR-RTF and Population Council & \\
\hline 9:00-9:30 & Opening Ceremony & $\begin{array}{l}\text { Statements from: } \\
\text { - National Coordinator, Uganda } \\
\text { - ICGLR Chair, Republic of Congo } \\
\text { - IGP, Uganda } \\
\text { - ICGLR Executive Secretary } \\
\text { - Guest of Honor }\end{array}$ & MC \\
\hline $9: 30-9: 40$ & Review of Meeting Agenda & $\begin{array}{l}\text { Chi-Chi Undie } \\
\text { Population Council }\end{array}$ & \multirow{4}{*}{ IGP, Kenya } \\
\hline 9:40-10:00 & $\begin{array}{l}\text { ICGLR- RTF Training Program on } \\
\text { Combatting SGBV: Progress and Future } \\
\text { Activities with ICGLR Member States }\end{array}$ & $\begin{array}{l}\text { Nathan Byamukama } \\
\text { ICGLR-RTF }\end{array}$ & \\
\hline $10: 00-10: 30$ & $\begin{array}{l}\text { Q\&A-Remarks from the Floor } \\
\text { on Member States' Needs in Relation } \\
\text { to the Training Program }\end{array}$ & $\begin{array}{l}\text { George Odwe } \\
\text { Population Council }\end{array}$ & \\
\hline $10: 30-10: 50$ & TEA BREAK & & \\
\hline $10: 50-12: 00$ & $\begin{array}{l}\text { Member States' presentations } \\
\text { on collaborations between health } \\
\text { and police sectors to address SGBV } \\
\text { Presentations are to be brief, no more } \\
\text { than } 5 \text { to } 8 \text { mins. We ask each MoH } \\
\text { delegate for } 1 \text { slide with no more than } \\
3 \text { to } 5 \text { bullet points on any such } \\
\text { collaborations of which they are aware. } \\
\text { The list is not meant to be exhaustive, } \\
\text { just to highlight key collaborations. } \\
\text { If there are any gaps after each } \\
\text { presentation, IGPs from each country } \\
\text { are welcome to add to the } \\
\text { presentation. }\end{array}$ & $\begin{array}{l}\text { Jane Harriet Namwebya } \\
\text { Population Council (facilitator) } \\
\text { - Burundi delegation } \\
\text { - Central African Republic } \\
\text { delegation } \\
\text { - Republic of Congo delegation } \\
\text { - Democratic Republic of Congo } \\
\text { delegation } \\
\text { - Kenya delegation } \\
\text { - South Sudan delegation } \\
\text { - Sudan delegation } \\
\text { - Uganda delegation } \\
\text { - Zambia delegation }\end{array}$ & IGP, Congo \\
\hline $12: 00-12: 10$ & $\begin{array}{l}\text { Introduction to Africa Regional SGBV } \\
\text { Network }\end{array}$ & \multirow{2}{*}{ Chi-Chi Undie, Population Council } & \multirow{4}{*}{$\begin{array}{l}\text { IGP, South } \\
\text { Sudan }\end{array}$} \\
\hline $12: 10-12: 45$ & $\begin{array}{l}\text { A Survivor's Testimony (Great Lakes } \\
\text { Region) and Discussion }\end{array}$ & & \\
\hline $12: 45-13: 00$ & $\begin{array}{l}\text { Emergency Contraception: } \\
\text { A Technical Briefing }\end{array}$ & $\begin{array}{l}\text { Wilson Liambila } \\
\text { Population Council }\end{array}$ & \\
\hline 13:00-14:00 & LUNCH & & \\
\hline 14:00-15:00 & $\begin{array}{l}\text { Presentation of an Innovative, Police- } \\
\text { led SGBV Intervention: The Police } \\
\text { Provision of Emergency Contraception } \\
\text { Model }\end{array}$ & $\begin{array}{l}\text { George M. Phiri, Zambia Police } \\
\text { Jonathan K. Mwansa, Zambia MoH }\end{array}$ & \multirow{4}{*}{ IGP, Zambia } \\
\hline 15:00-15:30 & $\begin{array}{l}\text { The Police Provision of Emergency } \\
\text { Contraception: History of Regional } \\
\text { Policy Engagement }\end{array}$ & $\begin{array}{l}\text { Didacus Kaguta, EAC } \\
\text { Department of Peace and Security }\end{array}$ & \\
\hline $15: 30-16: 00$ & $\begin{array}{l}\text { The Police Provision of EC Intervention: } \\
\text { Discussion and Q\&A }\end{array}$ & $\begin{array}{l}\text { Nachela Chelwa, } \\
\text { Population Council }\end{array}$ & \\
\hline $16: 00$ & Wrap Up and TEA BREAK & Nathan Byamukama, ICGLR-RTF & \\
\hline
\end{tabular}




\begin{tabular}{|c|c|c|c|}
\hline \multicolumn{3}{|c|}{ Day 2: Tuesday, April 9, 2019} & \\
\hline 9:00-9:15 & Recap of Day One & \multirow{3}{*}{ Mike Mbivzo, Population Council } & \multirow{3}{*}{ IGP, CAR } \\
\hline 9:15-10:00 & $\begin{array}{l}\text { Integrating the Police Provision of EC } \\
\text { Model into the Police Sector in the } \\
\text { Great Lakes Region: Response from } \\
\text { Police Chiefs and MoH representatives }\end{array}$ & & \\
\hline 10:00-11:15 & $\begin{array}{l}\text { Deliberation by Police Chiefs } \\
\text { over Potential Policy } \\
\text { Commitments/Statements with } \\
\text { support from MoH Representatives } \\
\text { Reporting by Member States }\end{array}$ & & \\
\hline 11:15-11:45 & TEA BREAK & & \\
\hline 11:45-12:15 & $\begin{array}{l}\text { Discussing the Outcome Document: } \\
\text { Presentation of consolidated policy } \\
\text { statement/commitment for approval } \\
\text { by Member States; Discussion }\end{array}$ & \multirow[t]{2}{*}{ ICGLR-RTF } & \multirow{3}{*}{ IGP, DRC } \\
\hline 12:15-12:30 & $\begin{array}{l}\text { Deliberation over Strategies for } \\
\text { employing the } \\
\text { Statement/Commitment to promote } \\
\text { utilization of the Police Provision of EC } \\
\text { Model in the Region }\end{array}$ & & \\
\hline $12: 30-13: 00$ & Wrap Up and Closing & $\begin{array}{l}\text { ICGLR } \\
\text { Population Council } \\
\text { Guest of Honor }\end{array}$ & \\
\hline
\end{tabular}




\section{Appendix 2: Meeting Participants}

Burundi-Dr. Juma Ndereye

Democratic Republic of Congo-Col. Ebua Gobula Sebastien • Dr. Lily Mokako Gen. Philemon Patience

Central African Republic-Dr. Aime Dodane

Kenya-Alice N. Mwangangi • Dr. Chi-Chi Undie • Dr. George Odwe • Joyce Ombeva Linda Munyendo Chief of Police Symon Nyaga - Wilson Liambila

Republic of Congo-Col. Jean Roger Kouni-Okogna • Miambazila Matoko • Dr. Paul Oyere

South Sudan-Dr. Alexander Dimiti • Kuol Gabriel • Gen. Majak Malik • Mark Mayon • Martha John

Sudan--Dr. Manal Hassan Taha

Uganda-Adrine Atwine - Azokire John - ACP Basalirwa Jamal • AIGP Grace Tulyagumanawe Gudoi Isaac • Innocent Byaruhanga - Jane Harriet Namwebya - J.B. Mugerwa - Jotham Kabuusu Kaboneva S. • Dr. Kamya John • SP Katusa Marion - ASP Kayongo Aisha • Lucy Ladira Paul Mukumbya Natamba Derrick - Moses Karuhanga - Muchunguzi Moses • Nathan Byamukama Natukewa Philemon Ngobi James • Dr. Nuwamanya Emmanuel • Patience Bahiira ACP Polly Namaye • Sharon Asiimwe • Twinamasiko Amon • Tumesime Robert

Zambia-Dr. Angel Mwiche - Dr. George Msipu Phiri • Chief of Police Lombe Bwalya Kamukoshi Dr. Mike Mbizvo • Dr. Mwansa J. Kaunda • Nachela Chelwa •

EAC Secretariat-ACP Didacus Kaguta 

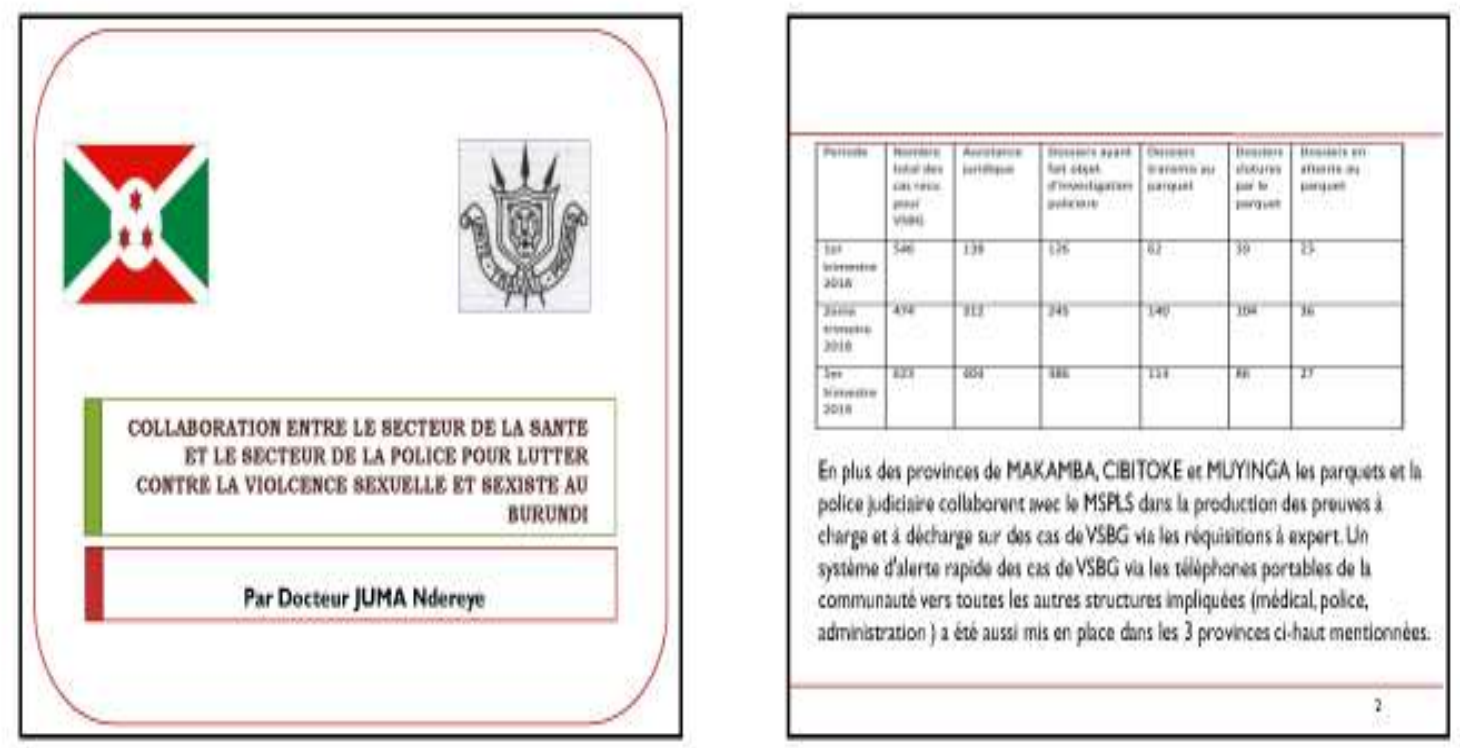

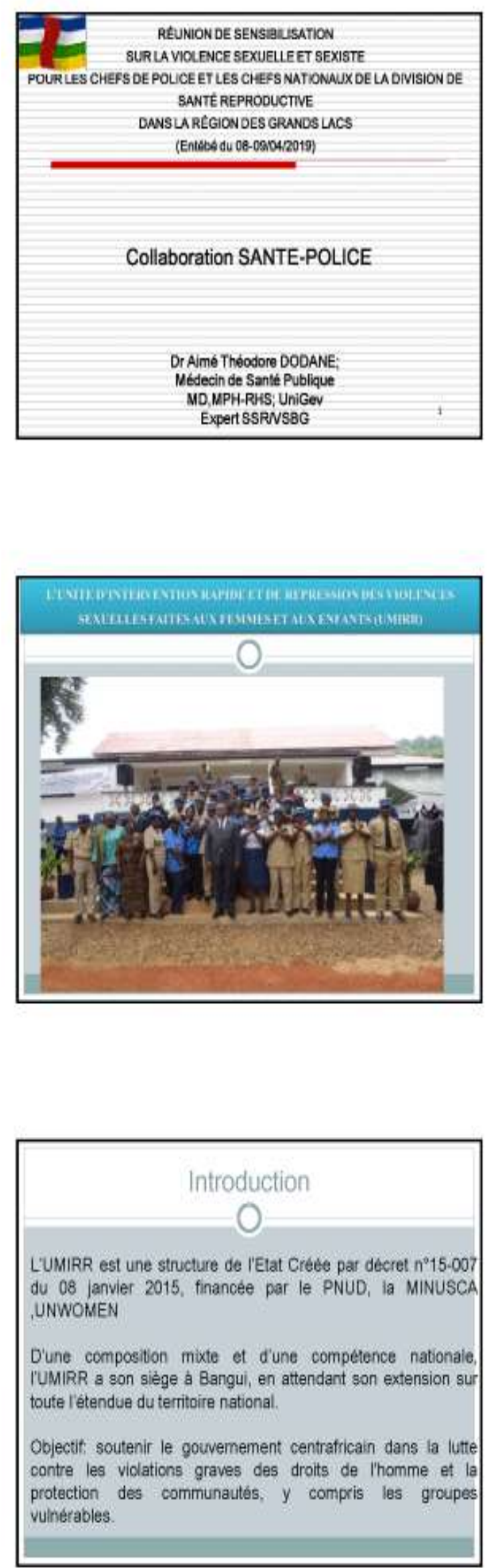

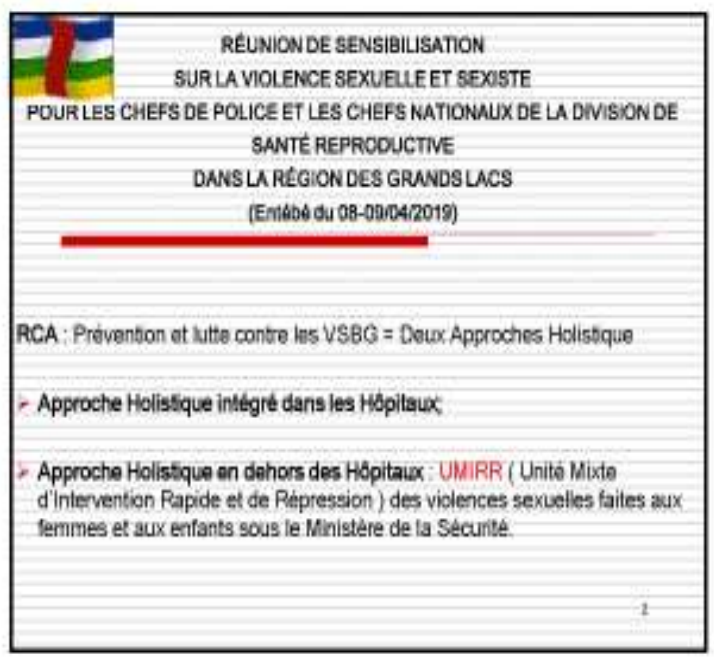

\section{Contexte et justification}

Les Viotences Sexualles et Basees sur le Genre (VSBG), longtamps ignorbes en RCA ont prs de lampleur en 2002-2003 of entre 2012-2013 aux ples farts moments des crises militiso-politiques qui ont secoué le pays.

Les statistiques de sources autorsées et disponibies à ce jour établissent par millers le nombre de victimes formelement identifieses et particuierement répandues pami une frange de la populaton la plus wulnerable.

En effet, seuls les femmes et les enfants payent le lourd tribut des affres des VSBG Celte situation alarmante a suscité les réactions des autorites centraficanes et de la communaute internationale.

Dans le cas de la RCA, pour iutter contre l'mpunsté de ces graves violations das Droils de thomme et prandre an chargo les victimes des VSBG lengagement de la communaute intemationale ef des autorites centrafricanes a ette maverialise entre autres par la creation de rUMIIR?

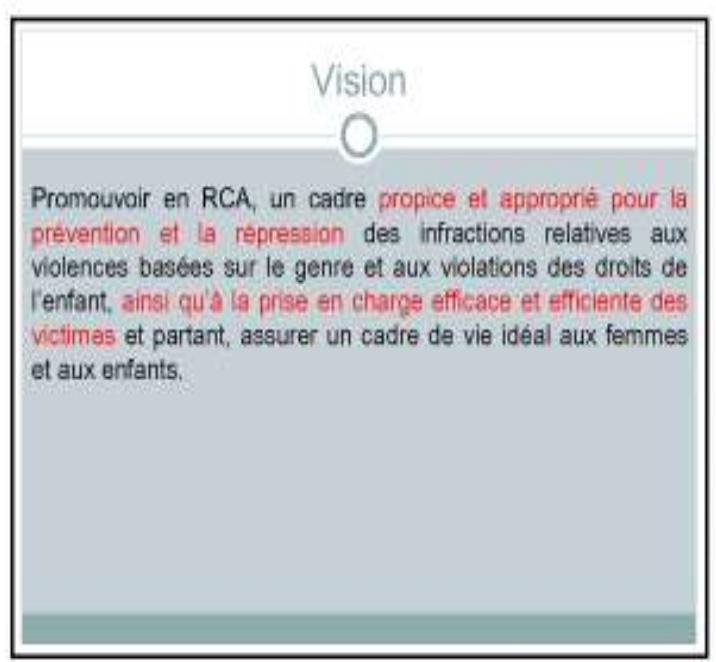



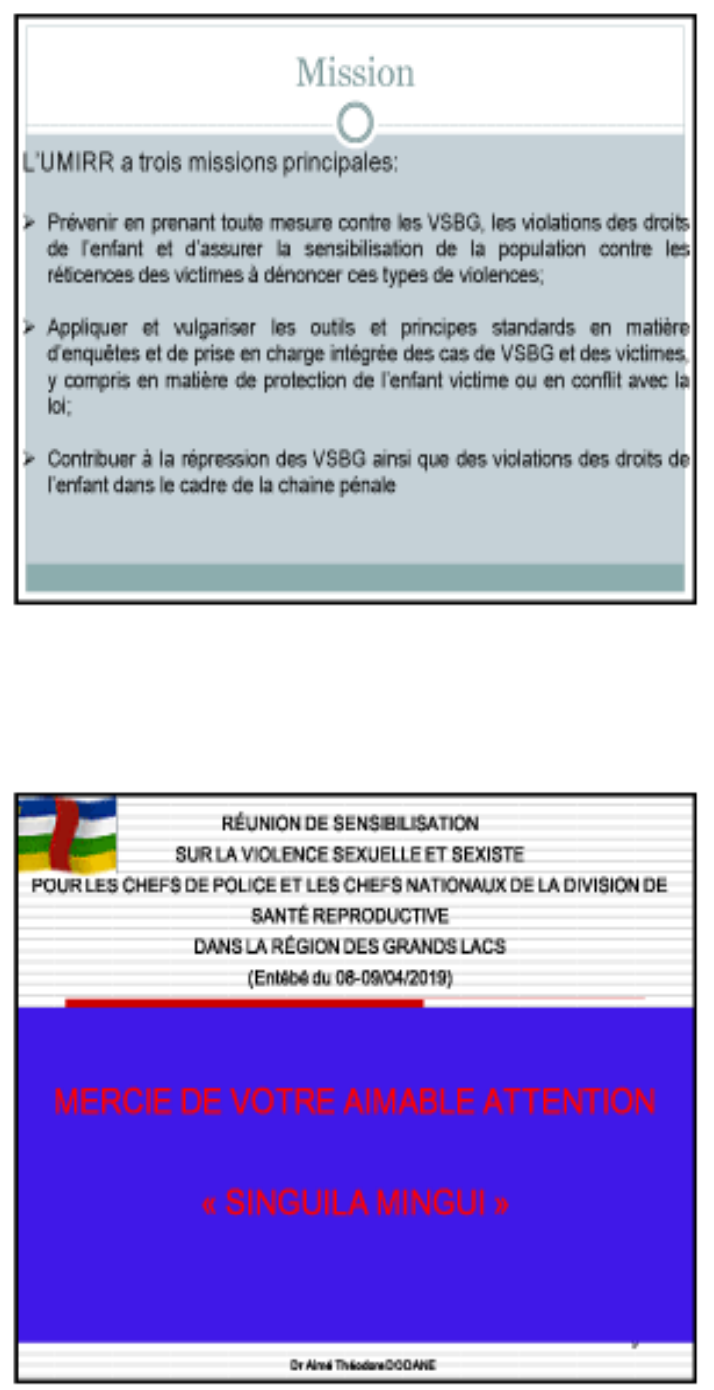

\section{Structure}

L' UMIRR à une direction composée de quatre services:
- Un service de Prévention, d'Intervention et d'Alerte;
- un service d'Enquêtes et d'Investigations;
un Service de Prise en Charge Médicale et Psychosistance Juridique et Judiciaire.




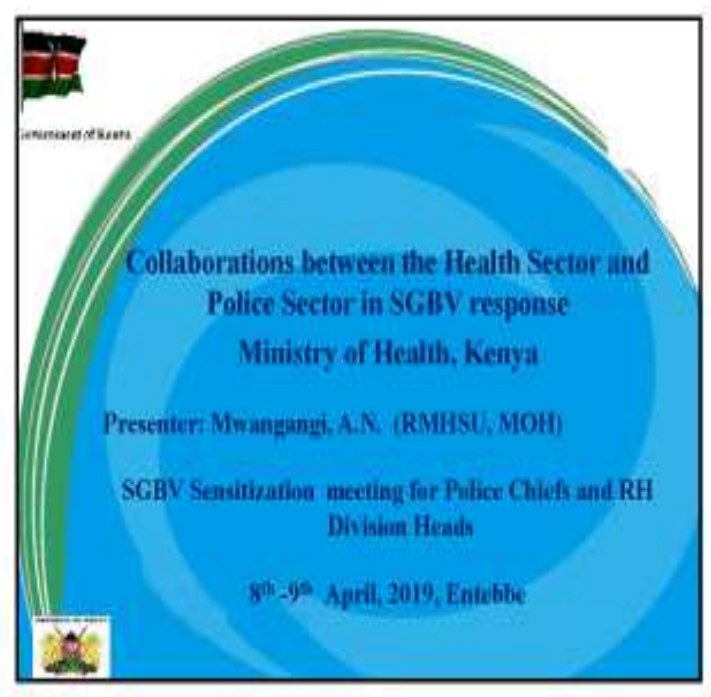

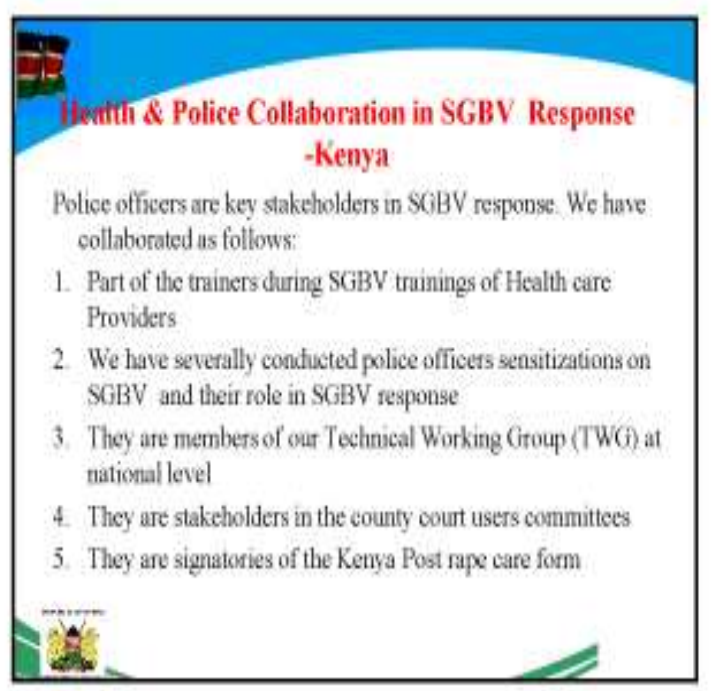

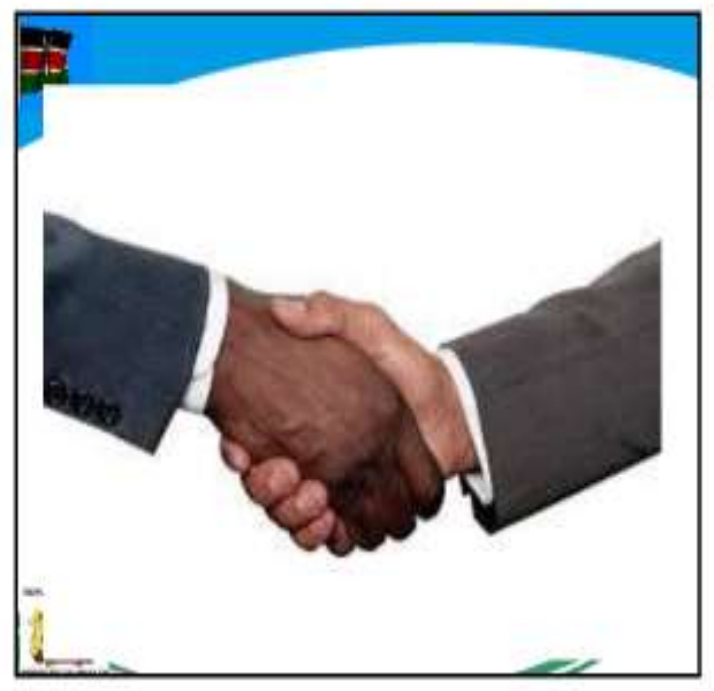




\section{IMPLEMENTATION DE}

LA CONTRACEPTION D'URGENCE

MODELE CONGOLAISIRC ENTEBBE LE 09 AVRIL 2019

CONTEXTE

L'EXISTENCE OUN PRONET VBg DANS LA POLICE

- COCUMENTS OU PRONET( Bruchesel guido)

DNUMERO VERT 1444

_DISPONIBUTE DEB CONTRACEPIFB

POUMOUE DES ONTERVENTIONS A BASE COMMUNAUTARE DE SANTE

FORAATION DES FORMATEURS

IDERTIFICATION DES COMMISSAFUT'S PIOTES

\section{ACTIVITES A MENER}

FORMATION SUR LA CONTRACEPTION D'URGENCE ET ISTINIH DES POLICIERS FORMATEURS

DOTATION CONTRACEPTION DUREENCE DES COMMISSARIATS PILOTES

- BUIMUEVALUATION

VULGARISATION DE LA OEMARCHE AU NIVEAU DELECOLENATIONALE SUPERIEURE DELA POLIOE

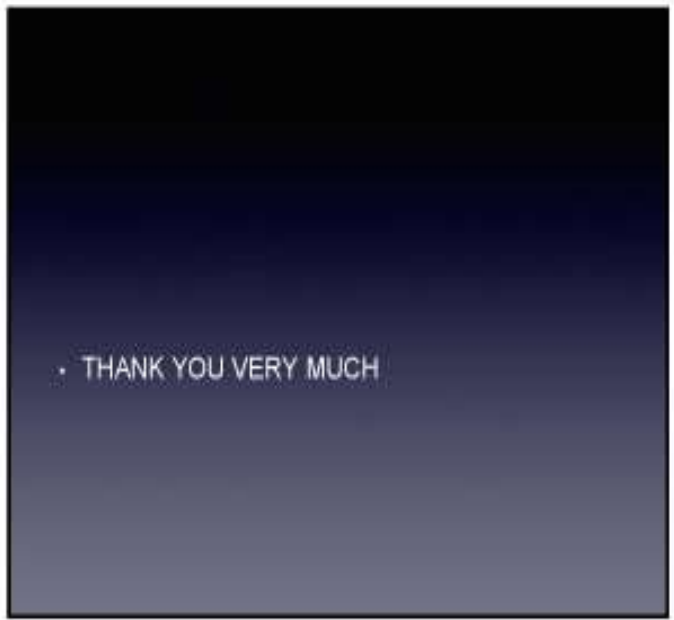

\section{BESOINS}

- APPUI FINANCIER POUR LES FORMATIONS

APPUI FINANCIER POUR L'ELABORATION DU MANUEL DE LA CONTRACEPTION DURGENCE AU SEIN DE LA POLICE 


\begin{tabular}{|c|}
\hline South Sudan MOH\& Police \\
\hline collaboration in Gender and GBV: \\
\hline $\begin{array}{l}\text { - Partnership of appropriately trained Health and Police personnel to } \\
\text { ensise estabishment of } 5 \text { pecial Protection Units (SPU) within police } \\
\text { stations and hesalth facilities to provide sensitive services to GEV } \\
\text { survivors. }\end{array}$ \\
\hline $\begin{array}{l}\text { - Conduct training of health and police SPU officeers on appropriate } \\
\text { GEV case management. }\end{array}$ \\
\hline $\begin{array}{l}\text { - Ptovide pre-service training on gender and GaV to all health and } \\
\text { police personnet. }\end{array}$ \\
\hline $\begin{array}{l}\text { - Cooperate with Police (MOU) to mnsiste comprehensive services that } \\
\text { include examination of survivors, provisian of required treatment/ } \\
\text { PEP, EL, STI), collection of forensic evidence, Receive complaints } \\
\text { from GEV sirvivors, provide immediate prychosocial counselling. }\end{array}$ \\
\hline $\begin{array}{l}\text { - Coopurate with pofike in Conducting Proper investigation and } \\
\text { documentation of GEV cases, ensuring avalistiility and accessibility } \\
\text { of police form } 8 \text { free of charge. }\end{array}$ \\
\hline
\end{tabular}



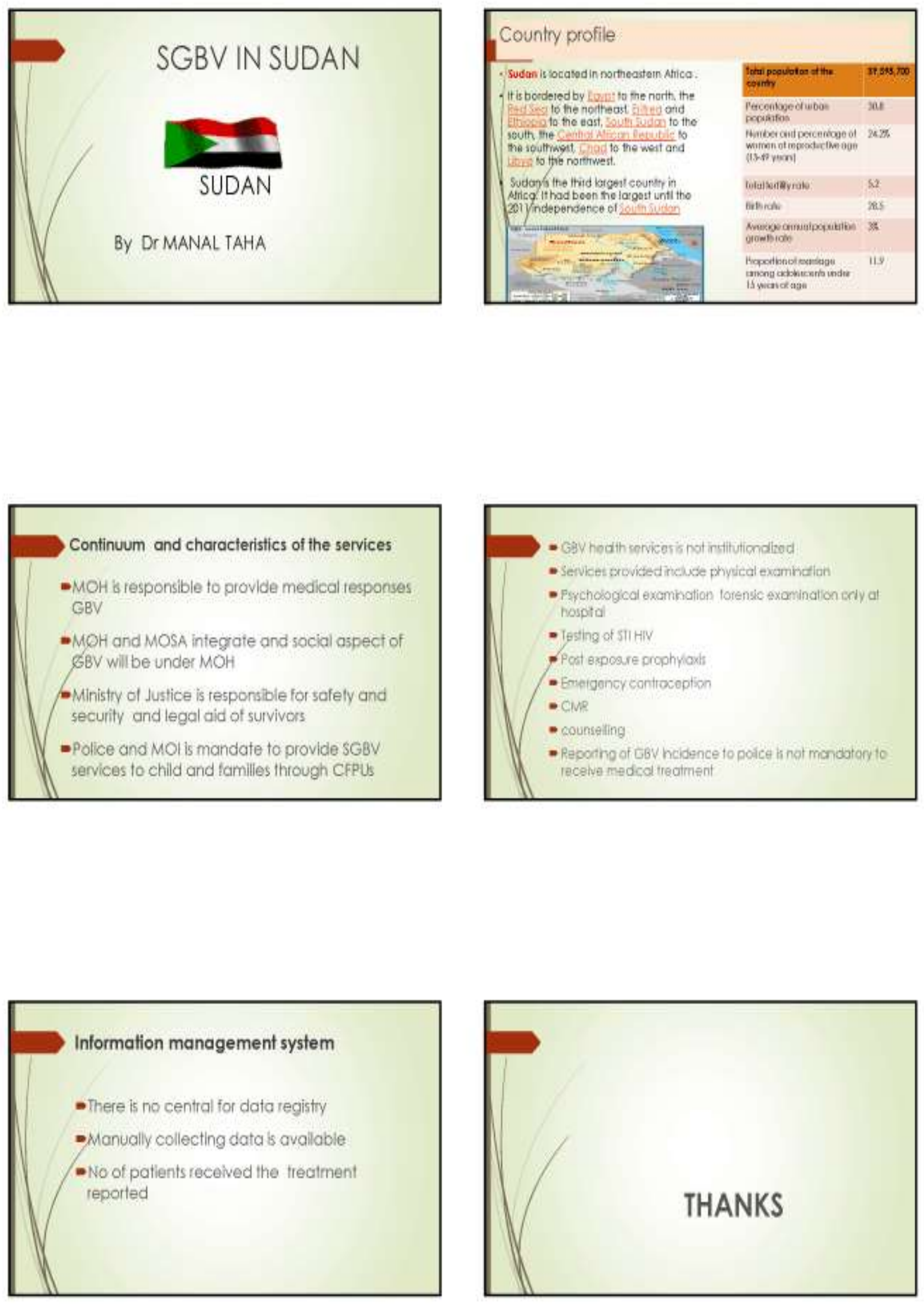


\section{PRESENTATION BY UGANDA}

\section{Meeting the Needs of Sexual Violence Survivors in the Great Lakes Region by Working with the Police Sector.}

Apri 8-9a" 2019 take Victoria Serene Hotel

\section{What has been achieved?}

\section{\5GBV POUCY FORMULATION}

Government through the ministry of health formulated SGBV policy and guidelines this works as a standard of laws covering areas ofScreening for SGBV cases at point care Reporting in the SGBV register

Diagnosis procedures

Examination, referral and report writing

\section{Continuation}

Enabling laws

In addition to the penal code, Uganda parliament passed a law

to enforce SGBV related cases.

\section{Ministry of health police and JLOS}

Spear headed revision of police medical forms PF3A and PF244.

The revised forms permitted medical practitioners other than doctors to examine survivors.

\section{Continuation}

$>$ Police child and family protection units. (PCFPU).

The force used a special unit to handle SGBV cases and is run by officers trained and oriented in SGBV area. SGBV now integrated into training schools for all police officers.

$>$ Government through JLOS partnership with police CID created a fund to facilitate medical examination of SGBV. 

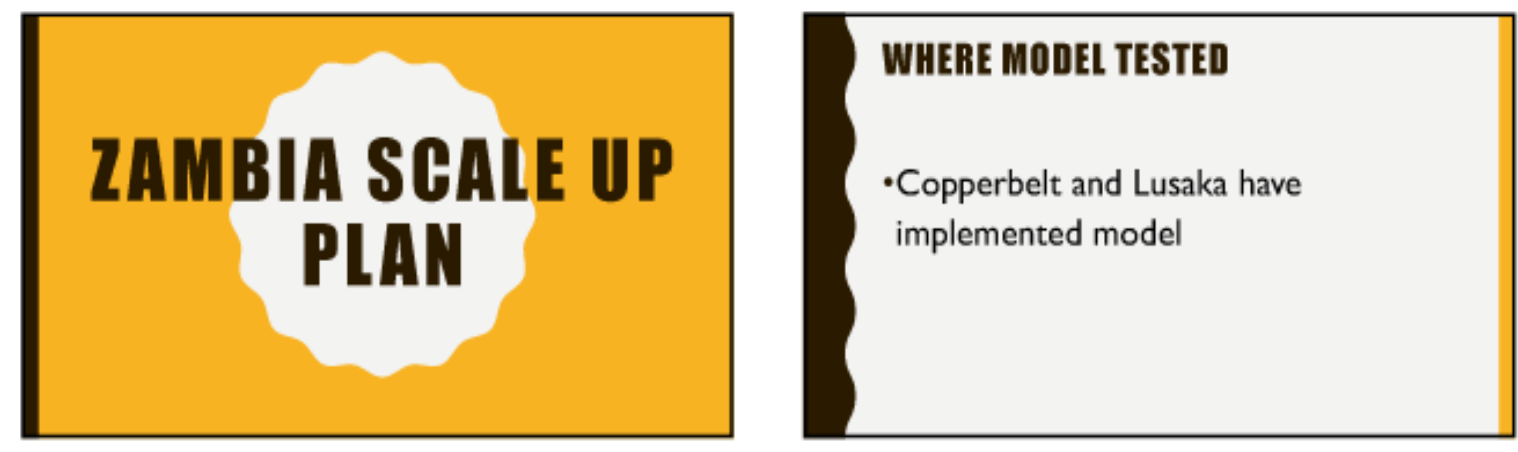

\section{CHALLENGES IM MODEL} IMPLEMENTATION

- Limited Transport

-Supply chain - access to the drug for police sites

- High turn over of offices

\section{STRENGTHS IN MODEL} IMPLEMENTATION

-Presence of community based distributors

- Model incorporated in the curriculum in Police and nursing schools (Pre-service and In-service)

\section{NEXT STEPS}

- Target Provincial roll-out:All provincial police stations to start EC distribution

- Trin provincial and district police officers with EC provision by Police - Assess VSU monthly returns to identify high incidence of rape and defilement and target those for scale-up.

- In addressing supply cha in issues - MoH to support the training of Police along with $\mathrm{CBD}$ in respective communities to allow trained police obtain drugs from clinics in locality of Police station/posts.

-Discass this with FPTWG to plan actual training for scale ue

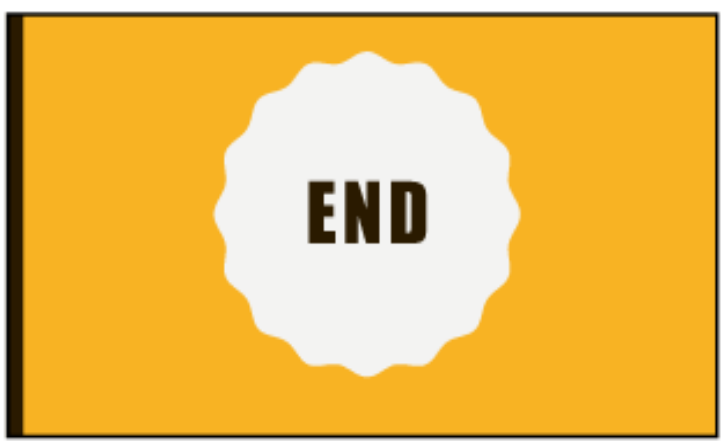



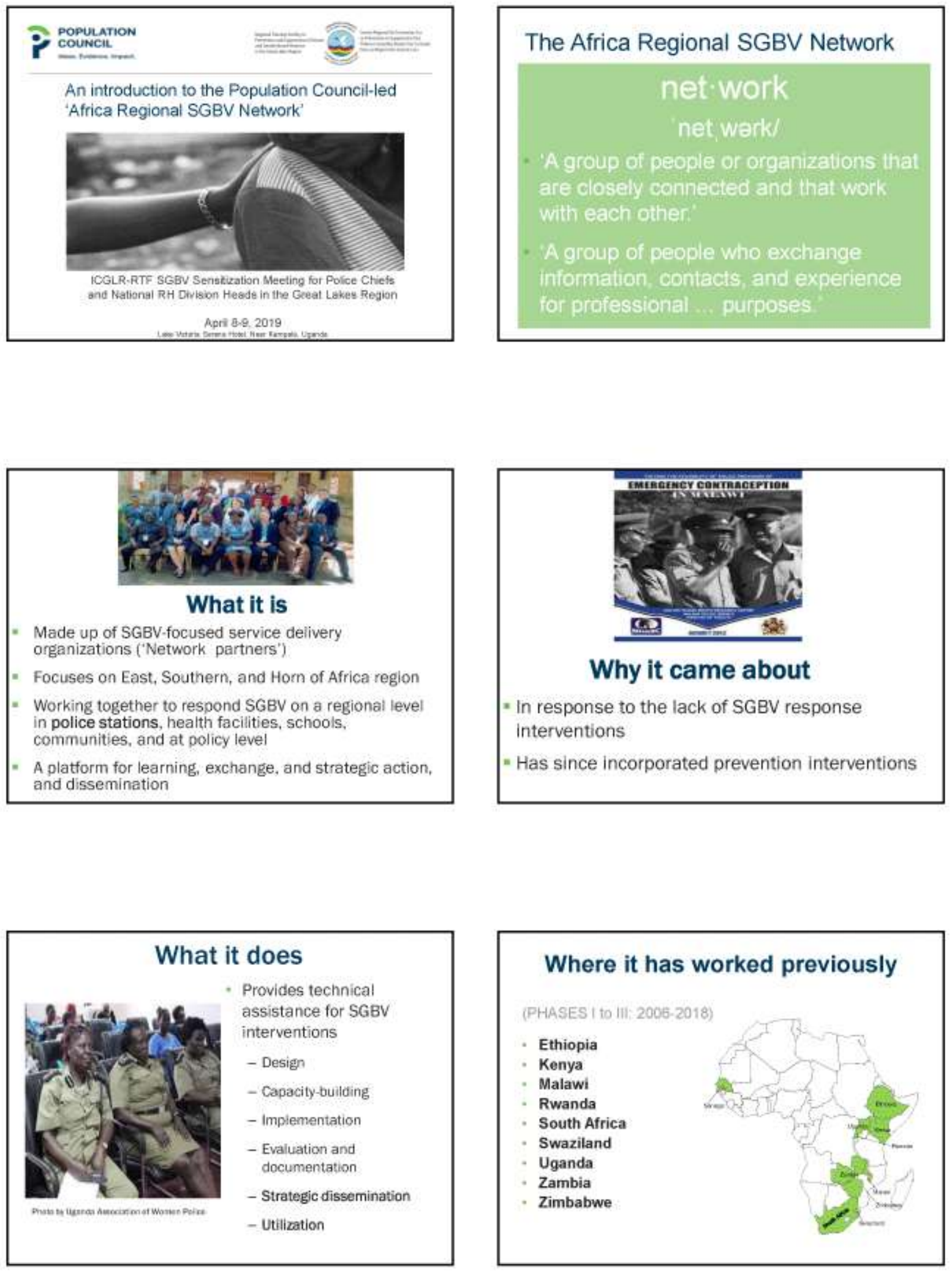

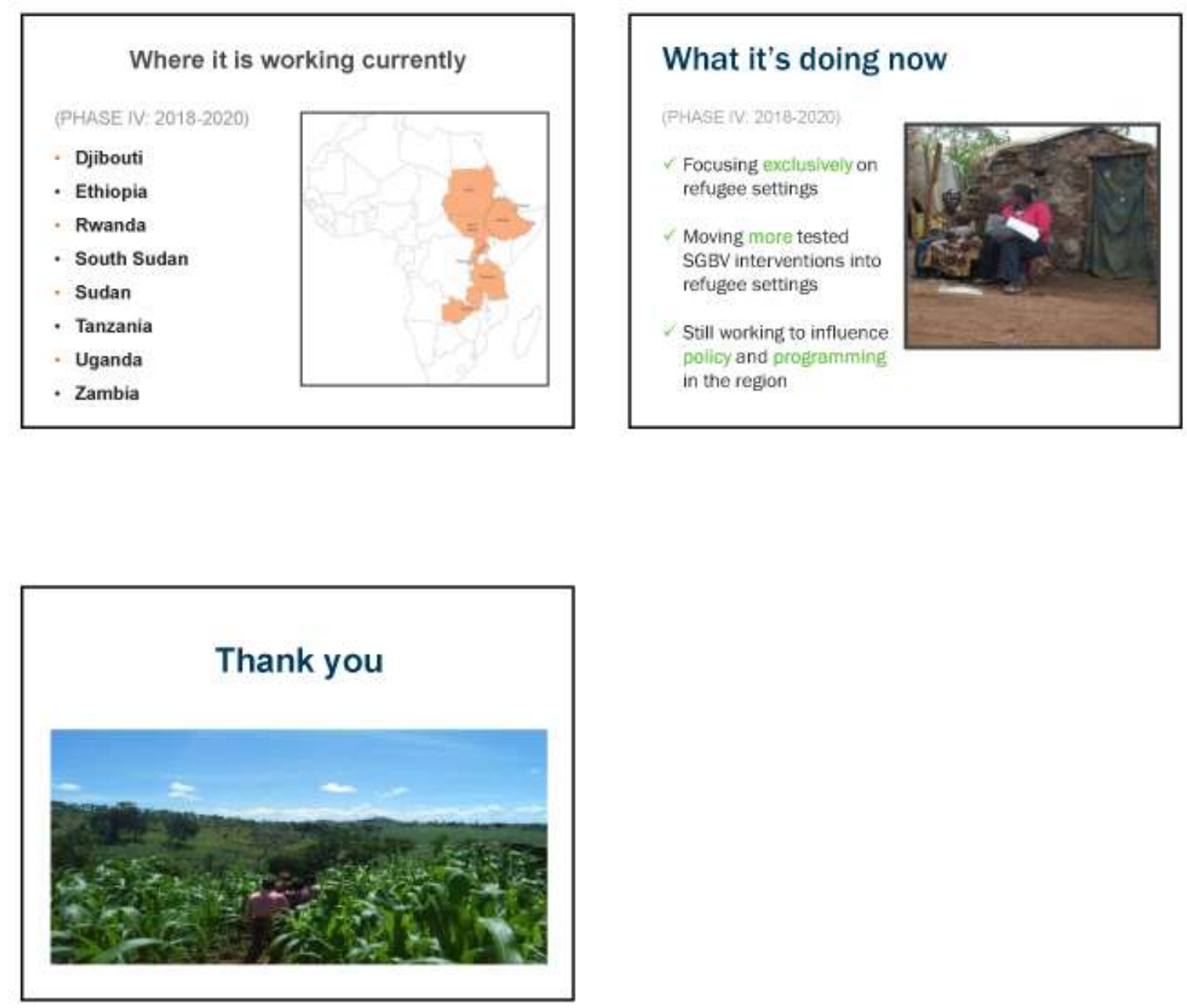


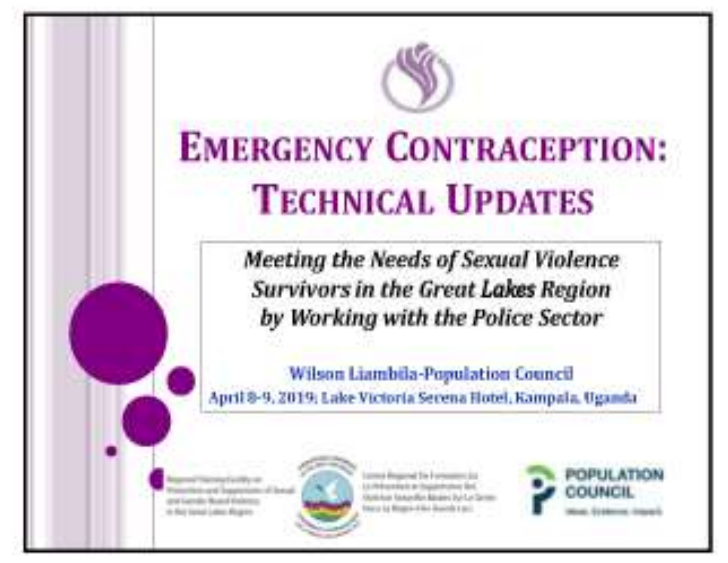

THE NeXt 15 Minutes ...

- What is EC?

o Why do women use EC?

- Types of EC

oECP Regimen updates

o How EC pills work

- How safe EC is

- Repeated use of EC

- Other clinical considerations

o Counseling Women on EC

\section{WHAT IS EMERGENCY CONTRACEPTION?}

- Emergency contraception $[\mathrm{EC}$ ) refers to the use of cartain contraceptive methods by women to prevent pregnancy after unprotected sexual intercourse, EC provides emergency protection (prevents pregnancy) for about $75-95 \%$ of those at risk.

- EC can reduce unwanted pregnancies that might lead to: $\checkmark$ child neglect,

$\checkmark$ abandonment,

$\checkmark$ unsafe asortions, and

$\checkmark$ maternal deaths.

o EC is an important element in post-rape care and in the PMTCT of HIV, and it is an essential component of quality FP service provision.
WHY DO WOMEN USE EC?

- Condom broke

- Late for an injection

o Forgot to take daily birth control pills

- Did not abstain from sex during fertile period

- Sex was not planned

- Unable to negotiate contraceptive use with partner

- Sexual assault

Amy woman who had unprotected sex and does not want to get pregnant can use EC

\section{TYPES OF EC}

o Pills

- Levonorgestrel ECPs, $1.5 \mathrm{mg}$ or $0.75 \mathrm{mg}$ (most common type)

- Regular oral contraceptive pills in higher doses (Yuzpe

regimen)

- Other pills (such as ulipristal acetate)

o Copper IUD

This presentation focuses primarily on levonorgestrel ECPs. Some common brand names include Postinor-2 and Norlevo.

\section{ECP REGIMEN: UPDATES}

- Timeframe: ECP5 are more effective the sooner they are taken after unorotected sex, but can provide some protection for up to 5 days ( 120 hours).

- Dosage: Women can take LNG ECPs as a single dose of $1.5 \mathrm{mg}$. When using the two-pill product, women can take both ollls at the same time.

- 1 dose of $1.5 \mathrm{mg}$ is as effective as 2 doses of $0.75 \mathrm{mg}$.

- Taking 1 dose is simpler than taking 2 doses 12 hours apart. 


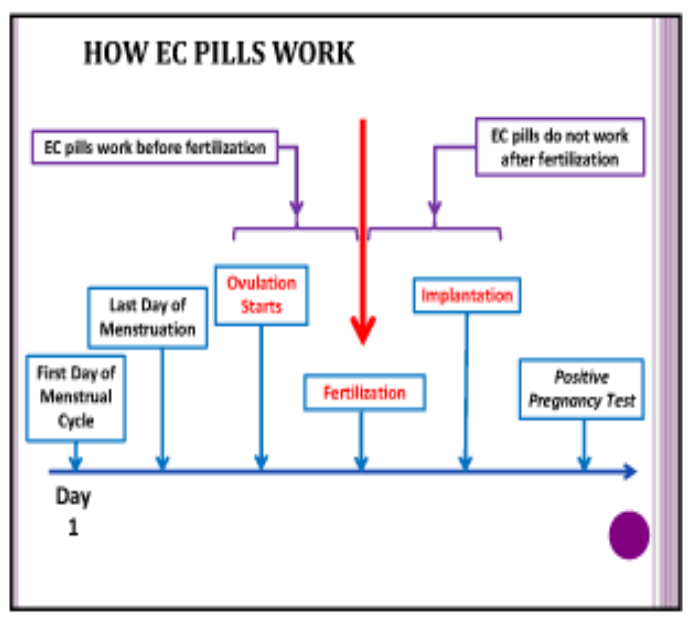

How SAFE IS EC?

oNo effect on future fertility

o No increased risk of cancer, stroke, or ectopic pregnancy

oWill not harm a fetus or cause birth defects if a woman is already pregnant

\section{WHO fact sheet on EC:}

"Levonorgestrel-alone emergency

contraception pills are very safe and do not

cause abortion or harm future fertility. Side-

effects are uncommon and generally mild."

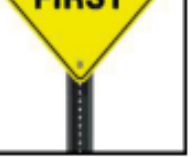

WHAT ABOUT REPEAT USE OF EC?

o Most importantly: repeat use of EC is safe.

- The WHO's 2015 Medical Eligibility Criteria states: "there are no restrictions on repeated uset of ECPS.

- It is safe even when women take it more than once in the same menstrual cyde.

- Taking ECPs is ALWAYS safer than carrying an unwanted pregnancy to term or resorting to unsafe abortion.

o Using a regular, ongoing method is recommended as the most effective way to prevent pregnancy.

\section{Clinical Considerations}

O Is a pregnancy test needed?

- WHO guidance does not support pregnancy testing as a requirement for EC provision.

- When during a woman's cycle should EC be offered?

- Anytime durine the womar's cycle, as it is diffcult to predict the timing of ovalation.

o Should anti-emetics be administered?

- Prophysactic administration of anti-emetics not needed for LNG ECPS.

o Who should be offered EC?

- All female survivors of rape, no matter their age, can/should be offered $\mathrm{EC}$, if they have begun menstruating or are otherwise beieved to be at risk of pregnancy (are there signs of secondary sou charactefistics?
COUNSELING WOMEN ON EC

o What info should be provided to women?

- Take as soon as possible; take both pills together if using the 2-pill regmen

- ECPs are very safe and cannot cause an abortion or affect an existing pregnancy

- EC may cause some minor side effects which will resolve on their own. There are no lone-term side effects.

- ECPs are effective but not 100\%; if you do not get your period within one week of when it's expected, see a health care provider

\section{In CONCLUSION}

It's always better safe than sorry.

(EC pills are so $\underline{\text { SAFE }}$ that they should ALWAYS be offered if there is ANY risk of unwanted pregnancy.) 


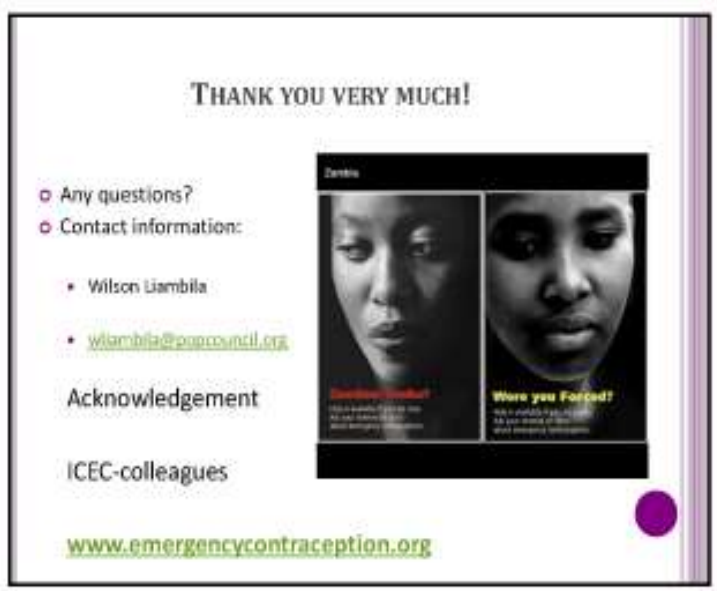




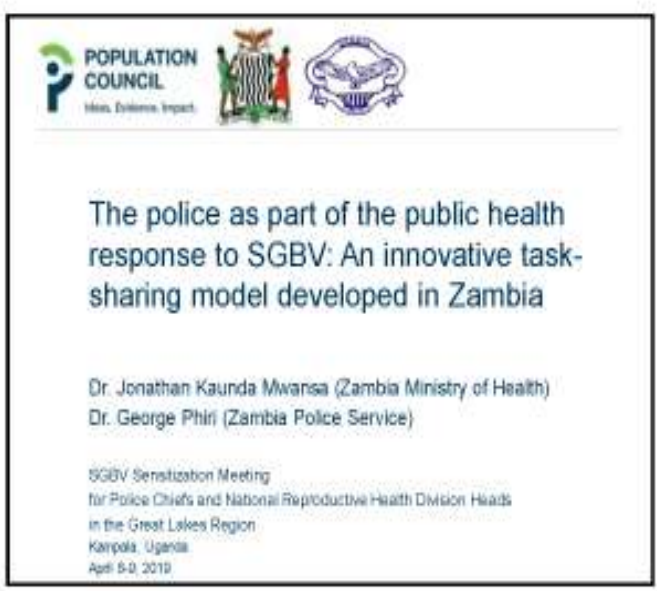

Formative research: Purpose and methods

- Conducted a formative assessment in 2005 to inform the intervention:

$\checkmark$ Review of SV records at 33 police stations \& posts and 19 health facilities in Copperbelt Province from January 2001 - December 2004

\section{Copperbelt Model of Integrated Care (CMIC) for sexual violence survivors}

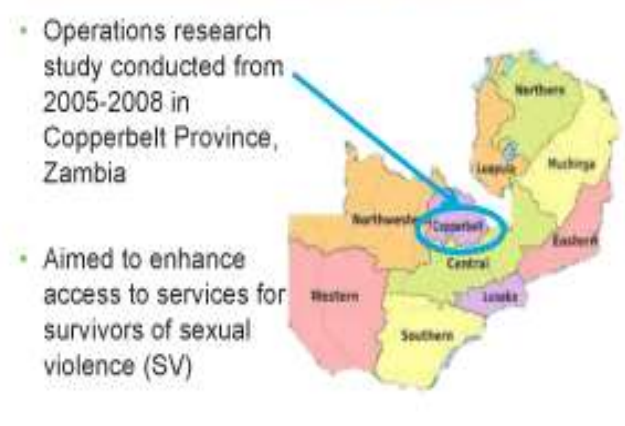

Key formative research findings from 2005

- Police often first and only point of contact for SV survivors

$-91 \%$ of all survivors first reported to the police

- Number of SV cases reported to the police

twice as many as the number that reported to health facilities during the same period

- SV services weak at health facilities

- $82 \%$ of cases artived in time for emergency contraception; but only $37 \%$ received it

Possible Solution: Collaboration between police and public health sector
Overview of collaboration between the police and the public health sector

$\checkmark$ Joint stakeholders' workshop (MoH, MHA, etc.) to review formative study findings and generate recommendations

$\checkmark$ Initial joint training of police \& health provider's

$\checkmark$ Later, cross-sectoral training (i.e, health providers trained police)

$\checkmark$ Joint police and heaith sector supervision

$\checkmark$ Cross-sectoral steering committee, held at police station or health facility, chaired by senior staff of hosting institution

\section{Stakeholders' workshop}

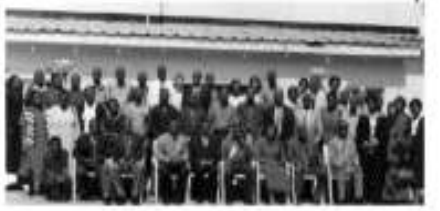

- Astakeholders meeting including representatives from Ministry of Health, Ministry of Home Affairs, Ministry of Community Development and Social Services, NGOs, and churches, was heid in 2005

- Formative assessment findings were reviewed and recommendations developed for improving the response to SV across police and public health sectors 

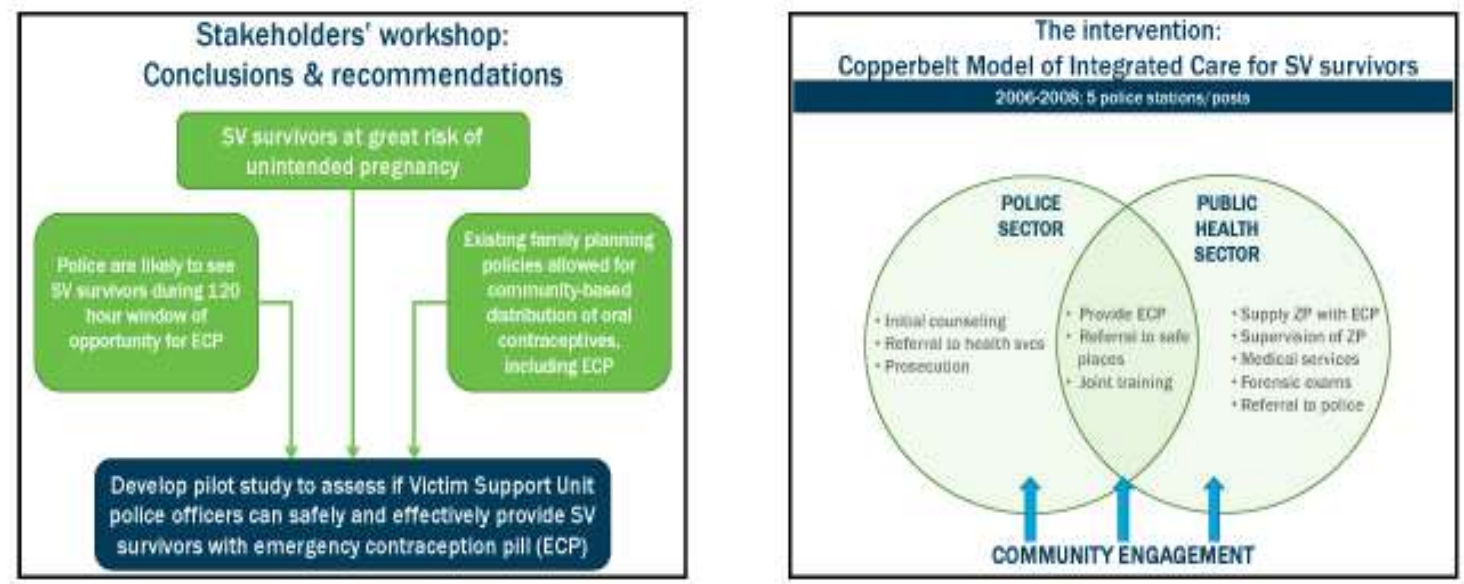

\section{On-site training}

- VSU officers who attended classroom trainings were expected to return to their facilities and train any officers that did not attend

- Trained health providers assisted the VSU officer's with the on-site trainings

Excerpt from client screening checklist

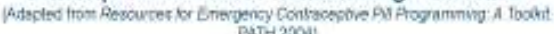

\begin{tabular}{|c|c|c|c|}
\hline 1. & Wus the cilient ingout/ dottod? & $Y=(60$ is 2$)$ & Cis \\
\hline 2. & $\begin{array}{l}\text { Dit the assault insobe oenetrativg } \\
\text { sex? }\end{array}$ & Ves ion to $x)$ & 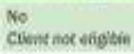 \\
\hline 3. & $\begin{array}{l}\text { Did the assault oceur wibsin the } \\
\text { past T2 hours? }\end{array}$ & Yes $(20$ is 4$\}$ & $\begin{array}{l}\text { No } \\
\text { Cilent not erigove }\end{array}$ \\
\hline 4. & 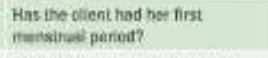 & Yes 150 in 5 5) & $\begin{array}{l}\text { No } \\
\text { clew not nigent }\end{array}$ \\
\hline 5 & $\begin{array}{l}\text { Does the client mant io prevent } \\
\text { pregnencef? }\end{array}$ & Yas $\{80$ in 6$)$ & $\begin{array}{l}\text { No } \\
\text { cilent not eigivie }\end{array}$ \\
\hline
\end{tabular}

eflex amanered YES wo questions 15 , she is elifeve for EC. Protee:

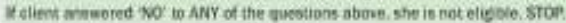
6. Hove elents eurrenily greeghant? Yos Cient noc wisigtie

Yithe elienki pregnancy seatus is unciear, EC iney stil be given but witsue

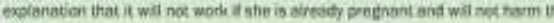

ECP provision at police stations and posts

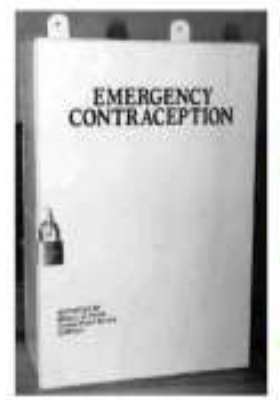

Each station given a set of basic supplies

Secured, locked box for ECP

Provider aids

a. Clert screening checklsts:

b. Standard operathy peocedures

3. Record-keeping tools

a. Survirot logtook

b. Monthly report foem

4. ECP commodities \& instructions

\section{Joint police and health sector supervision}

- District reproductive health coordinator and VSU coordinator conducted monthly

supervisory visits to each participating police

station \& post:

- Collected monthly reporting forms

- Reviewed all ECP checklists for accuracy and proper ECP provision

- Provided support \& discussed challenges with VSU officers

- Re-supplied ECP stocks and forms as needed 
Result 1 (analysis of service statistics and checklists) Police safely and effectively provided EC

- 357 doses of EC provided to SV survivors over 3 years

- No adverse events or complaints

- All doses provided to women and girls of reproductive age; never given to girls below age 10 (per study protocol)

Result 2 (analysis of service statistics)

Police referred clients at high rates

- Intervention definition of 'referral': provision of info on services available at health facilities, or accompanying survivor to a health facility

\begin{tabular}{|c|c|c|c|c|}
\hline \multicolumn{5}{|c|}{ 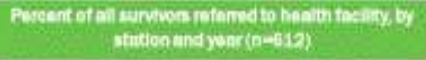 } \\
\hline 5tation & $\begin{array}{l}2006 \\
\$\end{array}$ & $\stackrel{2007}{4}$ & $\begin{array}{c}2008 \\
\$\end{array}$ & $\begin{array}{c}\text { Average } \\
: \%\end{array}$ \\
\hline Chitubu & 100 & 100 & 100 & 100 \\
\hline Kenshenshi & 100 & 100 & 100 & 100 \\
\hline Masola & 77 & 100 & 100 & 92 \\
\hline Kafulatuta & 92 & 86 & 0 & 59 \\
\hline Ndola Central & 5 & 3. & 8 & 5 \\
\hline
\end{tabular}

\section{Reflections}

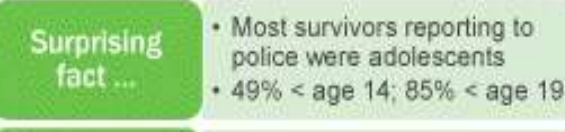

Could've done - We could control turnover of better if trained police

Need to think - How to address

more about transportation needs of referred clients

\section{Reference}

- Jill Keesbury, Mary Zama, Sudha Shreeniwas. 2009. The Copperbelt Model of Integrated Care for Survivors of Rape and Defilement: Testing the feasibility of police provision of emergency contraceptive pills. Lusaka: Population Council.

http://wnw.popcouncil.org/uploadsipd/s/2009RH ZambiaCopperbeltModellntCare.pdf

Thank you!

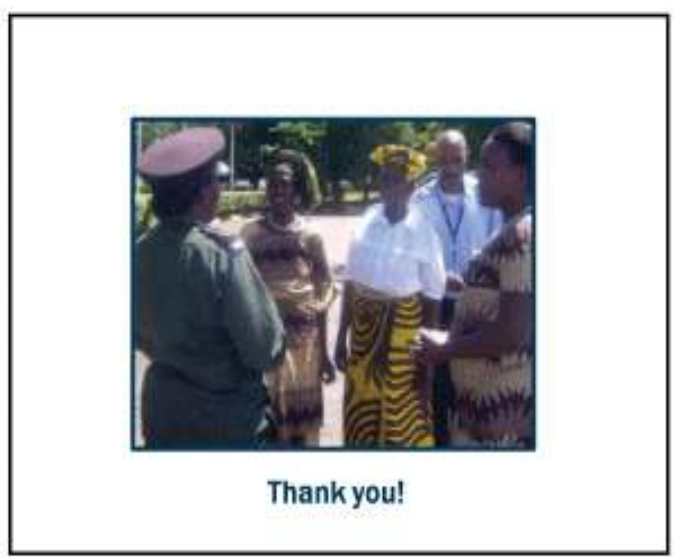

\section{How this intervention has been} scaled up so far

- Replicated successfully by police in Malawi (2011-2012)

- Incorporated into Zambia's national guidelines for managing SGBV survivors (2012)

- EC provision by police is included in Zambia's police training curriculum for new recruits

- The intervention is being considered by UNHCR Regional Service Center for replication in selected refugee settings in the East \& Horn of Africa region 


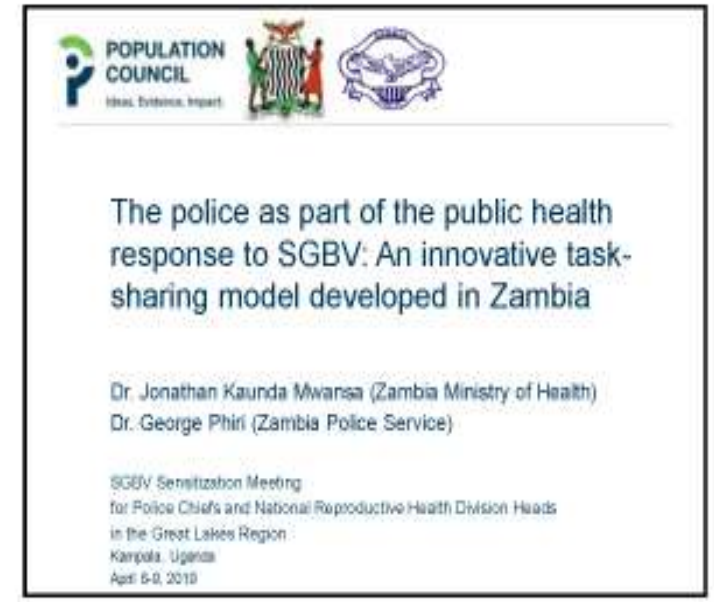

Formative research: Purpose and methods

- Conducted a formative assessment in 2005 to inform the intervention:

$\checkmark$ Review of SV records at 33 police stations \& posts and 19 health facilities in Copperbelt Province from January 2001 - December 2004
Copperbelt Model of Integrated Care (CMIC) for sexual violence survivors

- Operations research study conducted from 2005-2008 in Copperbelt Province, Zambia

- Aimed to enhance access to services for survivors of sexual violence (SV)

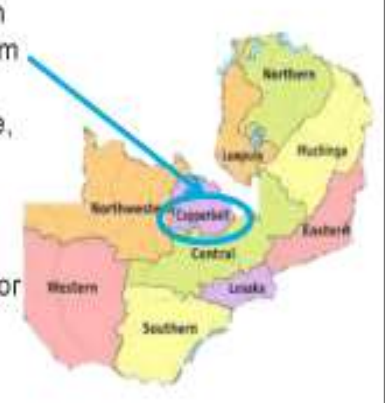

Key formative research findings from 2005

- Police often first and only point of contact for SV survivors

$-91 \%$ of all survivors first reported to the police

- Number of SV cases reported to the police twice as many as the number that reported to health facilities during the same period

- SV services weak at health facilities

- $82 \%$ of cases arrived in time for emergency contraception, but only $37 \%$ received it

Possible Solution: Collaboration between police and public health sector
Overview of collaboration between the police and the public health sector

$\checkmark$ Joint stakeholders' workshop ( $\mathrm{MoH}, \mathrm{MHA}$ etc.) to review formative study findings and generate recommendations

$\checkmark$ Initial joint training of police \& heaith providers

Later, cross-sectoral training (i.e., health providers trained police)

$\checkmark$ Joint police and health sector supervision

Cross-sectoral steering committee, held at police station or health facility, chaired by senior staff of hosting institution
Stakeholders' workshop

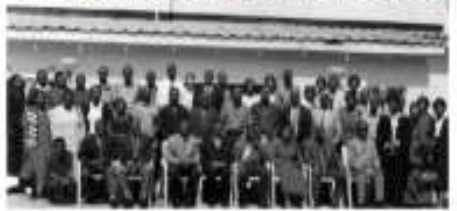

- Astakeholders' meeting including representatives from Ministry of Health, Ministry of Home Affairs, Ministry of Community Development and Social Services, NGOs, and churches, was held in 2005

- Formative assessment findings were reviewed and recommendations developed for improving the response to SV across police and public health sectors 

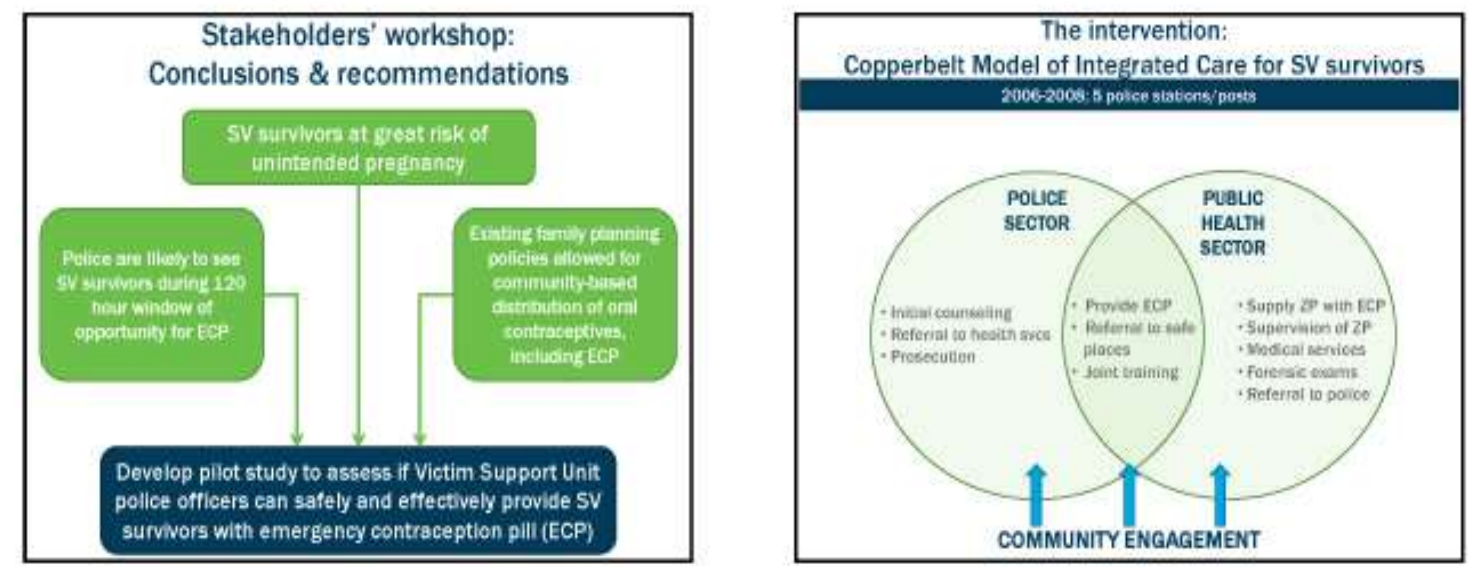

\section{On-site training}

- VSU officers who attended classroom trainings were expected to return to their facilities and train any officers that did not attend

- Trained health providers assisted the VSU officers with the on-site trainings

ECP provision at police stations and posts

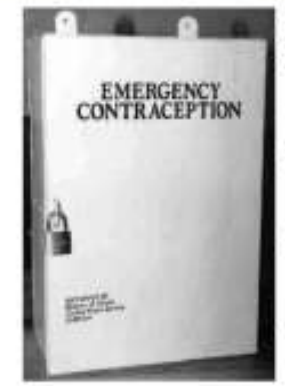

Each station given a set of basic supplies:

Secured, locked box for ECP

Provider aids

a. Clent screening chacklats

b. Standard operating peocedures

Record-keeping tools

a. Survinor logkook

b. Monthly rapont form

4. ECP commodities \&

instructions

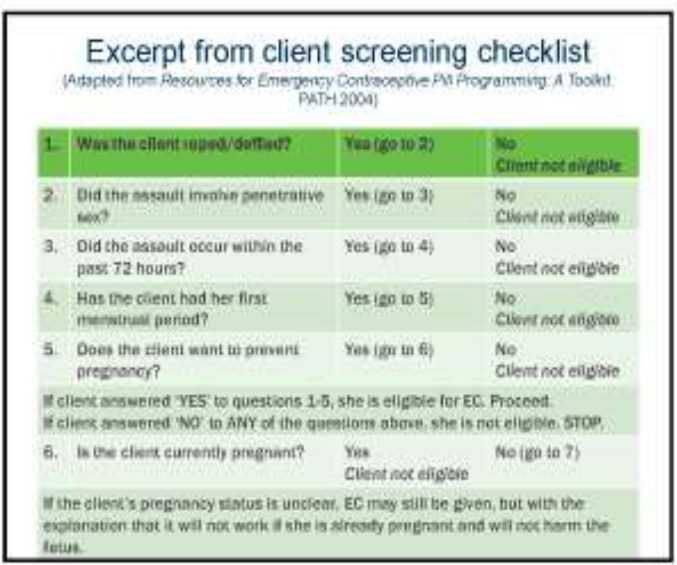

Joint police and health sector supervision

- District reproductive health coordinator and

VSU coordinator conducted monthly

supervisory visits to each participating police

station \& post:

- Collected monthly reporting forms

- Reviewed all ECP checklists for accuracy and proper ECP provision

- Provided support \& discussed challenges with VSU officers

- Re-supplied ECP stocks and forms as needed 
Result 1 (analysis of service statistics and checkists) Police safely and effectively provided EC

\section{- 357 doses of EC provided to SV survivors} over 3 years

- No adverse events or complaints

- All doses provided to women and girls of reproductive age; never given to girls below age 10 (per study protocol)
Result 2 (analysis of service statistics)

Police referred clients at high rates

- Intervention definition of 'referral': provision of info on services available at health facilities, or accompanying survivor to a health facility

\begin{tabular}{|c|c|c|c|c|}
\hline \multicolumn{5}{|c|}{ 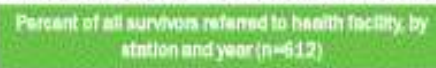 } \\
\hline Station & $\begin{array}{c}2006 \\
\%\end{array}$ & $\begin{array}{c}2007 \\
\times\end{array}$ & $\begin{array}{c}2008 \\
\%\end{array}$ & $\begin{array}{l}\text { Average } \\
\qquad /\end{array}$ \\
\hline Chifuba & 100 & 100 & 100 & 100 \\
\hline Kanshensal & 100 & 100 & 100 & 100 \\
\hline Masalia & 77 & 100 & 100 & 92 \\
\hline Katutatuta & 92 & 86 & 0 & 59 \\
\hline Ndole Central & 5 & 3 & 8 & 5 \\
\hline
\end{tabular}

\section{How this intervention has been} scaled up so far

- Replicated successfully by police in Malawi (2011-2012)

- Incorporated into Zambia's national guidelines for managing SGBV survivors (2012)

- EC provision by police is included in Zambia's police training curriculum for new recruits

- The intervention is being considered by UNHCR Regional Service Center for replication in selected refugee settings in the East \& Horn of Africa region

\section{Reference}

- Jill Keesbury, Mary Zama, Sudha Shreeniwas. 2009. The Copperbelt Model of Integrated Care for Survivors of Rape and Defilement: Testing the feasibility of police provision of emergency contraceptive pills, Lusaka: Population Council.

hitp://umw popcouncil.org/uploads/pd/s/2009RH ZambiaCopperbeltModellntCare.pdf

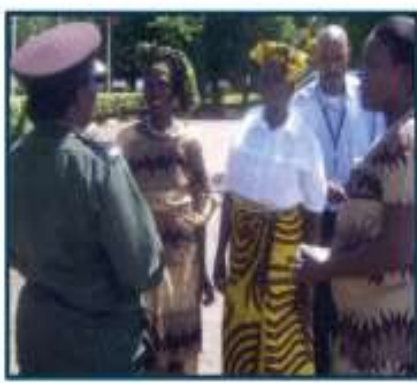

Thank you! 


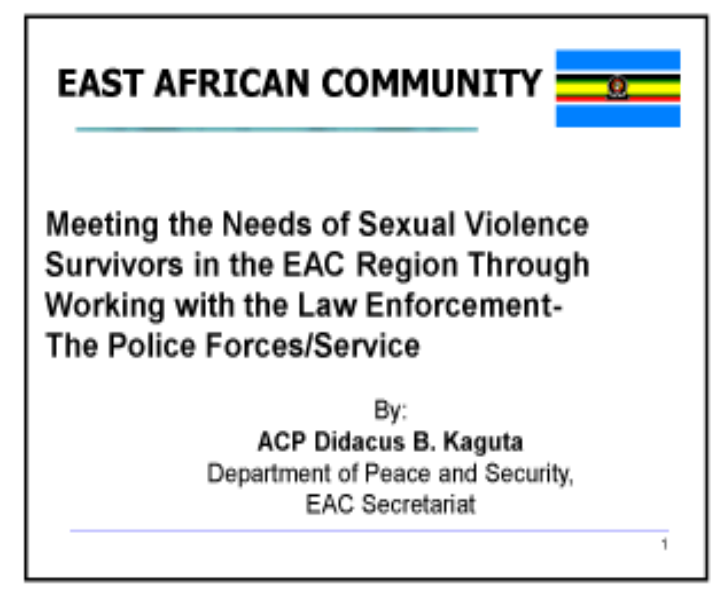

\section{$1^{\text {st }}$ Interventions}

1. Provision of emergency contraception (EC) by trained Police to SGBV survivors within 120 hours of an assault involving penetrative sex, followed by referral of these survivors to a health facility for further care.

- Police in the EAC region mostly first responders to survivors of SGBV and can therefore play an important role in pregnancy prevention for survivors of rape and defilement, and HIV prevention (PEP).

- Model been successfully tested with Police in Zambia and Malawi with excellent feasible \& effective results (no adverse effects or misuse)

- Outcome results prompted Zambia to scale up the model country wide, including PEP for HIV

- The EC model been now integrated in the National police training curriculum in Zambia

\section{Goal of the W/shop}

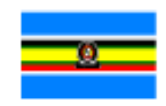

- To provide a forum for Police and Ministry of Health stakeholders to interact and explore ways of strengthening $S G B V$ interventions within the EAC region.

- To explore the possibility of expanding two key interventions in SGBV across the EAC, in order to meet the needs of sexual violence survivors in the region.

2nd Intervention
- Involves a multi-sectoral provider training model to improve the
collection, documentation, and utilization of medico-legal
evidence.
This training model (involving police and health providers) was
tested in Kenya by LVCT Health in collaboration with the
Ministry of Health and the police.
- Results: - significant improvement in police and health
providers accurately completing relevant police forms and
post-rape care forms for survivors.
- Proper completion of these forms enhanced survivors' access
to justice and facilitated timely prosecution of offenders.

Rep of Burundi
Police receives the victim and provides a referral to
the public hospital, whose findings facilitate court
processes.
- There are plans to establish a one-stop center in
Burundi.
there is need to recruit more female police, as there
are few in the country.
Burundi had 5 regions with 17 units. Each unit has a
dispensary, but the health service provision is not
adequate.

\section{Rep of Kenya}

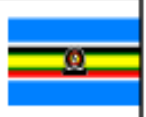

- Most laws in place

- Need to Create a one-stop center for survivors at County level, staffed with medical personnel, police, and paralegals staff

- Joint training for police, magistrates, community leaders, chiefs on SGBV

- SGBV be incorporated into pre-service police training

- Develop a multi-sectoral training manual for the country on SGBV 


\section{Rep of Rwanda}

- RNP has Isange one stop centre, which works closely with police and is situated in a Police Hospital.

- Isange is an EAC Regional Centre of Excellence on SGBV \& currently finished developing the Regional SOPs on GBV.

- All services at this Center are free, and the OSC itself provides basic SGBV training.

- SGBV part of the initial training curriculum in RNP

- Need for Joint training for Police officer on SGBV investigative techniques

- Need constant inservice trainings on SGBV snecialized skills \& scale un countrowide.

\section{United Rep of Tanzania}

- Have a training manual to train police specifically on how to respond to children and women victims of SGBV.

- SGBV is incorporated into the police training curriculum.

- Two One-Stop Centers for SGBV have been established in the country

- Need to train police officers who work at gender and child protection desks on police provision of EC model

- SGBV should be incorporated in both advanced/promotional \& command courses trainings

\section{Rep of Uganda} for police in Uganda.

- Regions and Metropolitan area have access to EC and each District Pol station has a medical unit.

- Each district has a dedicated Gender desk to handle Child and Family Protection Services including SGBV

- Need to conduct a feasibility study to see how the police provision of $\mathrm{EC}$ is working

- Kenyan model been going on in Uganda, but with limitations on escorting victims to the health facility and recovering the PF 3 A from the doctors.

$$
255 \mathrm{ep}-19
$$

- SGBV has been incorporated into the initial training

altial training
ccess to EC
cal unit.
esk to
vices
a, but with
alth facility

\section{Gen Observn Cont'd}

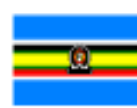

Enhance staffing within Police Gender Departments to ensure effective response;

- EAC to adopt the EAPCCO Standard Operating Procedures on SGBV;

- Emphasis on alcohol and narcotic drugs consumption as one of the major causes of SGBV

- Emphasis on preventive measures against SGBV essential

- Institute EAC a Thematic Working Group on Gender to address SGBV related issues in the region.

\section{Recommendations}

1. Direct the EAC Secretariat to mobilize resources and facilitate multi-sectoral trainings at national and regional levels on sexual and gender-based violence to enhance national and regional responses;

2. Direct the Secretariat to Partner with Population Council and organize learning exchange visits of the EAC police to Zambia Police Services and Kenya Police Service to facilitate the adaptation of the models described above to suit the EAC context and individual country contexts;

3. Direct the Secretariat to convene a meeting of experts drawn from Partner States to develop a regional training manual and Standard Operating Procedures on SGBV;

4. Organize Command Post exercises in response to SGBV at the finalization of the above manual and SOPs: 


\section{Recommendations cont'd}

5. Direct Partner States to consider incorporating the police provision of EC model into the EAC Partner States Police Training Curriculum;

6. Direct Partner States to incorporate SGBV education into the community policing function;

7. Direct Partner States who have not established One-Stop Centers on SGBV to do so;

8. Direct the Secretariat to adopt the EAPCCO Standard Operating Procedures on SGBV into EAC instruments

9. Direct the Secretariat to establish a Thematic Working Group on Gender to address SGBV related issues in the region.

10. Direct Partner States police services to collaborate closely with other stakeholders to foster strong multi-sectoral is coordination in SGBV and related causative crimes.

\section{Legal basis \& Related Initiatives}

- Initiatives on SGBV anchored in the provisions of the Treaty.

- Responses on SGBV cuts across many sectors of EAC such as Health, immigration, social sectors, Peace and security, etc.

- The EAC gender policy recognizes engendering P\&S Protocol, institutionalization of gender parity in peace \& security negotiations /mediation including addressing issues of SGBV

- EAC -APSA support Programme provides for implementation of the UNSCR 1325 which encompasses issues of Gender including SGBV

- So far trained two groups (62) Women security Officers on 1325 and managing conflict situations where SGBV is one of issues high on the agenda, $3^{\text {rd }}$ training upcoming soon.

\section{Related Initiatives}

- Establishing Gender forum by $3^{\text {rd }}$ quarter of 2019 and a gender thematic group to steer various gender related responses.

- Draft EAC Regional Framework on UNSCR 1325 to be concluded and adopted this year by the Council of Ministers

- Regional Center of Excellence on SGBV finalized SOPs on SGBV. Now drafting its Regional training manual.

- Stakeholders in SGBV multi-sectoral in nature, coordinated by the Interstate Security.

- Main stakeholders at EAC: Peace \& Security (Police, Immigration, prisons, GAL) Health, EALA, EACJ, CTC.

\begin{tabular}{|l|}
\hline THE END \\
THANK YOU FOR LISTENING \\
ASANTENI SANA KWA KUNISIKIRIZA \\
\end{tabular}

